\title{
Land use change from permanent rice to alternating rice-shrimp or permanent shrimp in the coastal Mekong Delta, Vietnam: Changes in the nutrient status and binding forms
}

\author{
Jens Kruse ${ }^{\mathrm{a}, \mathrm{b}, *}$, Maximilian Koch ${ }^{\mathrm{b}}$, Chau Minh Khoi ${ }^{\mathrm{c}}$, Gianna Braun ${ }^{\mathrm{d}}$, Zita Sebesvari ${ }^{\mathrm{d}}$, Wulf Amelung ${ }^{\mathrm{a}}$ \\ a Institute of Crop Science and Resource Conservation (INRES), Soil Science and Soil Ecology, University Bonn, Nussallee 13, 53115 Bonn, Germany \\ ${ }^{\mathrm{b}}$ Institute for Bio- and Geosciences - IBG-3, Agrosphere, Forschungszentrum Jülich GmbH, 52425 Jülich, Germany \\ ' Soil Science Department, College of Agriculture and Applied Biological Sciences, Can Tho University, 3/2 Street, Can Tho City, Viet Nam \\ ${ }^{\mathrm{d}}$ Institute for Environment and Human Security (UNU-EHS), United Nations University, Platz der Vereinten Nationen 1, Bonn 53113, Germany
}

\section{H I G H L I G H T S}

\footnotetext{
- Shrimp introduction improved nutrient status but lead to salt accumulations.

- Nutrients accumulated primarily in stable bonding forms.

- Shrimp effects were more pronounced in the sludges than in the soils underneath.

- Alternating rice-shrimp is a reversible, no-regret soil management strategy.

- Permanent shrimp systems adoption option in areas permanently affected by salinity.
}

\section{A R T I C L E I N F O}

\section{Article history:}

Received 17 June 2019

Received in revised form 28 September 2019

Accepted 29 September 2019

Available online 4 November 2019

Editor: José Virgílio Cruz

\section{Keywords:}

Salinity intrusion

Land use change

Aquaculture

Soil quality

XANES
G R A P H I C A L A B S T R A C T

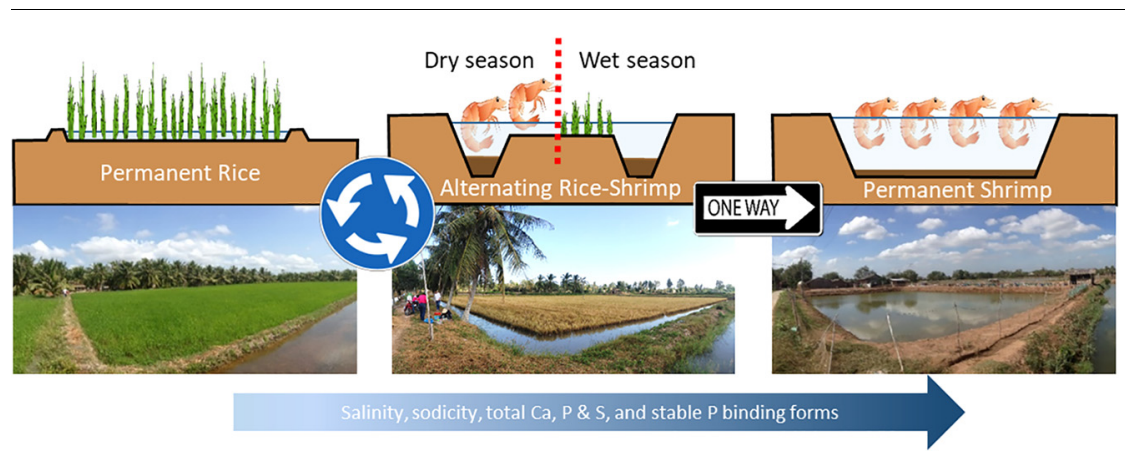

\begin{abstract}
A B S T R A C T
Saline water intrusion has become a severe threat in the coastal areas of Mekong delta of Vietnam, though offering farmers the option to diversify their land use, and switching, for instance, from permanent rice to alternating rice-shrimp systems or even to permanent shrimp systems. The objective of this study was to evaluate the respective impacts on soil salinity, nutrient status and their binding forms. Hence, we sampled the topsoils (cultivation layer, $0-15 \mathrm{~cm}$ ) from 10 permanent rice systems and the rice platforms of 10 alternating riceshrimp systems. Furthermore, the sludges and the soils $10 \mathrm{~cm}$ underneath of the sludges from the ditches of the alternating rice-shrimp as well as from ponds of the permanent shrimp systems were sampled in B n Tre and Sóc Trăng provinces, Vietnam, respectively. The samples were analyzed regarding their electric conductivity, total and plant-available nutrient contents. To reveal possible changes in nutrient binding forms, sequential $\mathrm{P}$ and $\mathrm{S}$ extraction, 31P-nuclear magnetic resonance spectroscopy, and S and P X-ray absorption near edge structure spectroscopy were applied. The results showed that permanent and alternating shrimp cultivation lead to elevated salt concentrations but also improved the overall nutrient status relative to the permanent rice management and especially in the sludges relative to the soils underneath. The continued deposition of shrimp and feed debris promoted the accrual of stable, Ca- and Mg-associated P forms as well as of P-monoesters, whereas the S forms were depleted in thiophene $S$ groups but enriched in sulfides relative to permanent rice fields. As effects by alternating rice-shrimp management were intermediate, this management has more potential to serve as a no-regret strategy for farmers to remain flexible in their response to climate changes and
\end{abstract}

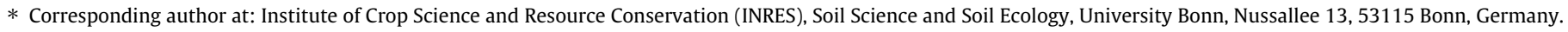
E-mail address: jens.kruse@uni-bonn.de (J. Kruse).
} 
concurrent salinity intrusion relative to permanent shrimp production, which requires strict maintenance of adequate salinity levels also during the rainy season.

(c) 2019 Elsevier B.V. All rights reserved.

\section{Introduction}

More than $40 \%$ of the world's population lives within $100 \mathrm{~km}$ of the coastline, placing immense pressure on local land and water resources (Atapattu and Molden, 2009). Many river deltas, which are especially fertile and highly populated coastal areas, experience drastic changes in agricultural land use systems, which can induce changes in the soil fertility as shown also in other regions of the world (Don et al., 2011; Guo and Gifford, 2002; Smith et al., 2016). Main drivers of these changes are droughts, salt water intrusion (both partially induced by climate change), as well as rapid socio-economic developments with respective changes in land use as adaptation to the changing environmental and economic conditions (Sebesvari et al., 2016). The Mekong delta in Vietnam is an example of such a fertile but vulnerable region with $64 \%$ of the land being used for agriculture with rice production dominating (GSO, 2018, 2016). However, especially in the coastal parts of the delta rice production is increasingly threatened by salinity intrusion from incoming seawater (Renaud et al., 2015), which is reaching progressively further inland. It is projected that salinity intrusion will increase in near future, e.g., by climate change induced sea level rise (0.3 m by year 2050) (Smajgl et al., 2015) and by anthropogenic induced land subsidence $(0.35$ to 1.40 m year 2050) (Erban et al., 2014; Minderhoud et al., 2017).

In response to these developments, land use in the Mekong delta is changing particularly in the transition zone between saline and fresh water areas. In formerly rice dominated areas intensive permanent shrimp cultivation increasingly co-occur with more extensive brackish water polycultures, such as alternating rice-shrimp farms or permanent rice farms (Joffre et al., 2018; Ottinger et al., 2016). These land use shifts from permanent rice to alternating rice-shrimp or even permanent shrimp farming represents both a diversification and at least partially also an intensification of agriculture towards economically more risky but also more profitable land use systems. Shrimp farming has the potential to increase the farmers' incomes by a factor of $\sim 5$ to 7 relative to solitary rice production (Phuong Lan, 2013) and was one of the main reasons for farmers to change to shrimp cultivation (Nguyen et al., 2019) along with the fact that it has also been pushed by the Ministry of Fisheries of Vietnam (Nhuong et al., 2002). However, shrimp is more risky than rice due to high investments, higher vulnerability to diseases, market price fluctuations, and varying salinity levels of pond waters (Joffre et al., 2018). Negative environmental impacts include a potential dispersion of antibiotics (Braun et al., 2019) and the salinization of water and soil (e.g., Tho et al., 2008), which may finally jeopardize economic benefits and also foster local competitions between rice and shrimp farmers for soil and water resources. Nevertheless, changes in soil properties and nutrient status after introducing shrimps into former permanent rice systems have hardly been studied up to now.

Shrimp farming can occur at various intensity levels, e.g., reflected in different stock densities, production cycles, use of feed additives, and pond design (Hai et al., 2015). For intensive shrimp cultivation, former paddy soils (Fig. 1A) are excavated, usually down to at least $\sim 2 \mathrm{~m}$. Sediment (so called sludge) can accumulate on the bottom of the pond, mainly consisting of inorganic eroded materials but also of decaying plankton, feces, and excess feed (Avnimelech and Ritvo, 2003; Funge-Smith and Briggs, 1998; see also Fig. 1A).
Less intensive but potentially more reversible shrimp aquaculture systems include co-culture of shrimp and rice and seasonal alternating cycles of rice (rainy season) and shrimp (dry season). These rice-shrimp systems were developed in response to the economic opportunities offered by high shrimp prices and support for production and income diversification from the government through favorable policies (Dung, 2012). In these systems, the traditional rice fields are amended with a ditch $(\sim 20 \%$ of the total area, water depth of $\sim 1 \mathrm{~m}$ ) and dike around the periphery of the field forming a platform (water depth of $\sim 0.3 \mathrm{~m}$; Fig. 1B). The alternating rice-shrimp system is a common land use in coastal salinity affected regions in the Mekong delta as it is well adapted to the contrasting salinity levels throughout the year, thus, allowing farmers to generate income in the dry season (e.g., Dung, 2012). It has many advantages over co-culture systems such as (i) higher water depth during rice or shrimp cultivation facilitating sufficient water temperatures and dissolved oxygen contents, (ii) rice stubble decomposition facilitates microbial food for aquatic species and fertilizer for the next cycle shrimp and the rice crop thereafter, and (iii) reduced insect pest pressure on rice due to interruption in their life cycle in alternating systems (Reddy and Kishori, 2019).

Although these changes are widespread, neither their impact on soil quality nor their reversibility is understood. Specifically, it is important for farmers and policy makers to know if the conversions alters soil fertility in such a way that there would be no return to former land use options, causing path dependencies and lock-in effects for farmerś future decision making options. Therefore, the present study aims to evaluate whether and to which degree a change from a permanent rice system to alternating or permanent shrimp cultivation affects soil quality and if these changes are likely reversible or permanent.

\section{Material and methods}

To evaluate long-term effects on the nutrient status in soil and sludge, we sampled permanent paddy rice systems as a control and compared their nutrient status with that of soils and sludges from alternating rice-shrimp and permanent shrimp systems. Samples were then characterized by their basic geochemical properties as well as by status in a range of total and available nutrients. A special focus was laid on changes in the phosphorus (P) and sulfur $(\mathrm{S})$ status in the three land agricultural use systems, because $\mathrm{P}$ is crucial for both rice and shrimp production and $\mathrm{S}$ may induce risks to the shrimp by exposing them to geochemical changes of sulfide deposits at the bottom of the ponds. To track changes in the $S$ and $\mathrm{P}$ binding forms according to the state of the art, we combined traditional wet chemical fractionation methods with advanced techniques such as ${ }^{31} \mathrm{P}$ nuclear magnetic resonance (NMR) spectroscopy and S and P K-edge X-Ray Absorption Near edge structure (XANES) spectroscopy as, e.g., recommended by Kruse et al. (2015).

\subsection{Sampling sites}

The study was conducted in the Mekong delta in the southeast of Vietnam, characterized by tropical monsoonal climate (mean annual temperature: $27^{\circ} \mathrm{C}$ and mean annual precipitation: $1660 \mathrm{~mm}$ (Delta Alliance, 2011). About 99\% of the rain falls within the rainy season from May to November, while the dry season from December to April experiences almost no rain. 


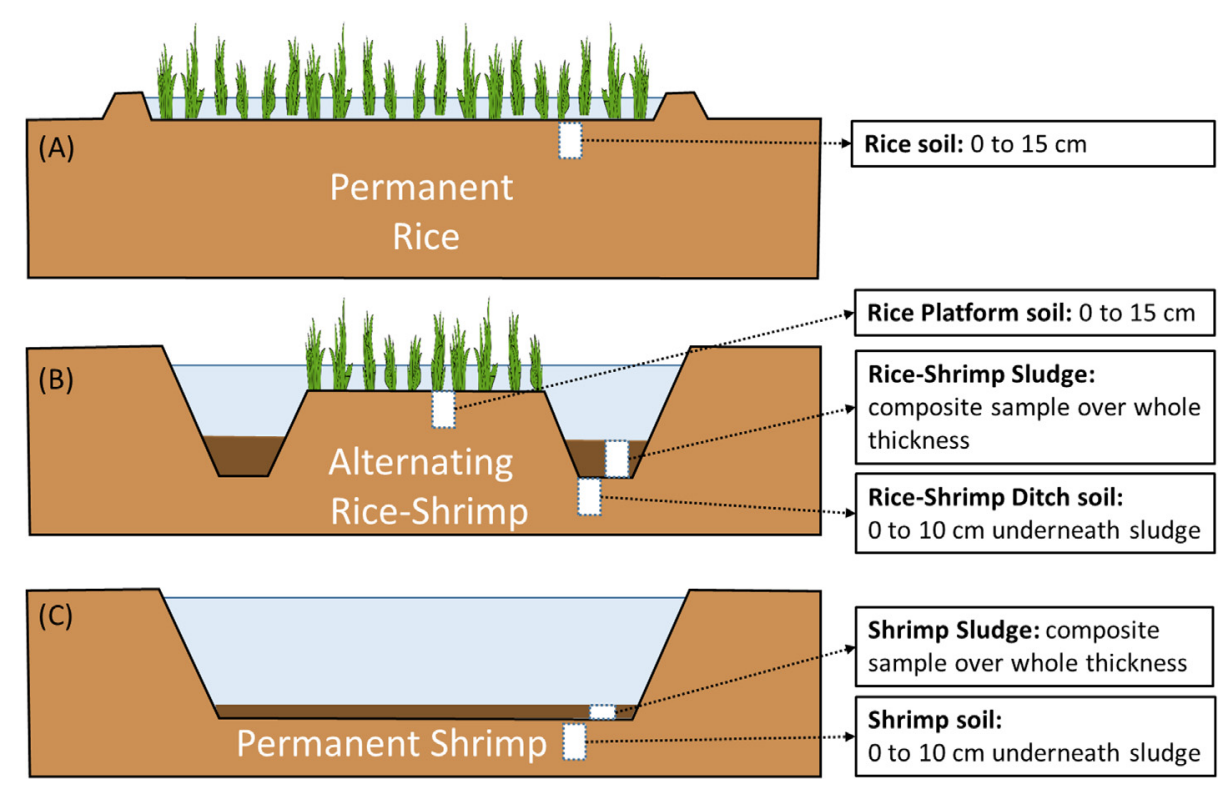

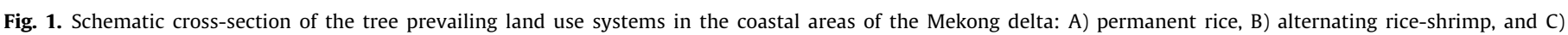
permanent shrimp.

The study sites were located in the districts Mỹ Xuyên and Vĩnh Châu of the province Sóc Trăng and in the district Thạnh Phú of the province $\mathrm{B} \mathrm{n}$ Tre. These provinces were chosen as they are characterized by similar climatic conditions (mean temperature: $27^{\circ} \mathrm{C}$ and mean annual precipitation B n Tre: $1500 \mathrm{~mm}$ and Sóc Trăng: $1700 \mathrm{~mm}$ ) as well as strong salinity gradients from the sea towards more inland with salinity-adapted land use systems (Renaud et al., 2015). In B $\mathrm{n}$ Tre the population density is 528 person per $\mathrm{km}^{2}$ (GSO-Database, 2016) with 58.4 thousand ha of paddy rice and 45.2 thousand ha of aquaculture (GSO-Database, 2017). Sóc Trăng is less densely populated (369 person per $\mathrm{km}^{2}$ (GSO-Database, 2016) and has a higher share of paddy rice in its land use with 348.2 thousand ha paddy rice and 74.1 thousand ha of aquaculture (GSO-Database, 2017). The production area of alternating riceshrimp in the Mekong delta was approximately 71,000 ha in 2000 and doubled rapidly to 152,977 ha by 2014 (Pham et al., 2015). Due to the increase, the overall area of alternating shrimp aquaculture reached $28 \%$ of the total area of the brackish shrimp production in the delta. The shrimp production from the alternating rice-shrimp system was 65 thousand $t$ in 2014, which accounted for $15 \%$ of the production in the Mekong delta region. In average, the alternating rice-shrimp system produces 300 to $500 \mathrm{~kg}$ of shrimp and 4 to $7 \mathrm{t}$ of rice per ha annually (Pham et al., 2015). In Sóc Trăng province, production area of alternating riceshrimp was 7,929 ha in 2010 and increased to 9,919 ha in 2014, contributing to $50 \%$ of the brackish shrimp production area in the province. $97 \%$ of the overall alternating rice-shrimp production of Sóc Trăng province is located in Vĩnh Châu district (Pham et al., 2015). Respective statistics are lacking for B n Tre province.

For this study, the following land use systems were selected for sampling along a salinity gradient in both provinces: i) permanent paddy rice systems with mainly double rice cropping (permanent rice), ii) alternating rice-shrimp systems with rice during the wet (September to January/February) and shrimp production during the dry season February/March to August/September (alternating rice-shrimp), and iii) permanent intensive shrimp systems (permanent shrimp) with two to four shrimp production cycles per year.

Based on interviews with local authorities and farmers as well as accessibility to fields for each land use system, ten representative field replicates were selected in each province and sampled within two weeks in January and February 2016 (Fig. 2). In the permanent rice systems paddy rice was cultivated for more than 50 years. In the permanent rice system, only freshwater is used for irrigation and chemical fertilizers are usually recommended to be applied at a rate of $80 \mathrm{~N} / 45 \mathrm{P}_{2} \mathrm{O}_{5} / 30 \mathrm{~K}_{2} \mathrm{O}\left(\mathrm{kg} \mathrm{ha}^{-1}\right)$. All alternating rice-shrimp fields had been converted from former paddy rice fields on average 20 years ago. In the alternating rice-shrimp system, farmers rely principally on rainfall for growing rice in the wet season, whereas the inundation of brackish water during the dry season favors the shrimp culture.

The permanent shrimp systems were converted from riceshrimp systems on average 9 years ago. In all ponds, saline water is maintained all year. Average shrimp stocking densities were higher in $\mathrm{B} n$ Tre (alternating rice-shrimp: 7 individuals $\mathrm{m}^{-2}$; permanent shrimp: 80 individuals $\mathrm{m}^{-2}$ ) than in in Sóc Trăng ( 3 individuals $\mathrm{m}^{-2}$ and 30 individuals $\mathrm{m}^{-2}$ ). In the permanent shrimp systems, commercial industrial feed was provided for the shrimps, whereas mainly natural feed was provided in the rice-shrimp system. No salt has been additionally added to any permanent shrimp or alternating rice-shrimp system. No data could be obtained on the amount of added fertilizer or feed for the individual fields.

For the permanent rice system and the platform of the alternating rice-shrimp system, topsoils (cultivation layer, 0 to $15 \mathrm{~cm}$ ) were sampled using a self-made stainless steel soil corer with $7 \mathrm{~cm}$ diameter. The pond bottom of the permanent shrimp system and the soils in the ditches of the rice-shrimp system were sampled using a sediment corer, also $7 \mathrm{~cm}$ in diameter (Hydro-Bios, Kiel, Germany). The latter cores were further subdivided into the sediment sludge (sludge) and the sediment $10 \mathrm{~cm}$ beneath it, which differed in color, density, and eventually texture (see Fig. 1 for the illustration of sampling scheme). Each time five cores were taken from random positions to yield one composite sample per sampled farmland. This pooling for obtaining a representative average, however, also resulted in a pooling of sludge samples over the entire thickness observed for a given land use system. The average sludge thickness in the alternating rice-shrimp systems was $22 \mathrm{~cm}$ (Sóc Trăng) and $17 \mathrm{~cm}$ (B $\mathrm{n}$ Tre), but only $6 \mathrm{~cm} \pm 1$ (Sóc Trăng) and $3 \mathrm{~cm}$ (B n Tre) in the permanent shrimp systems, respectively. The lower sludge thickness in the later system was due to more frequent sludge removal by the farmers as compared 


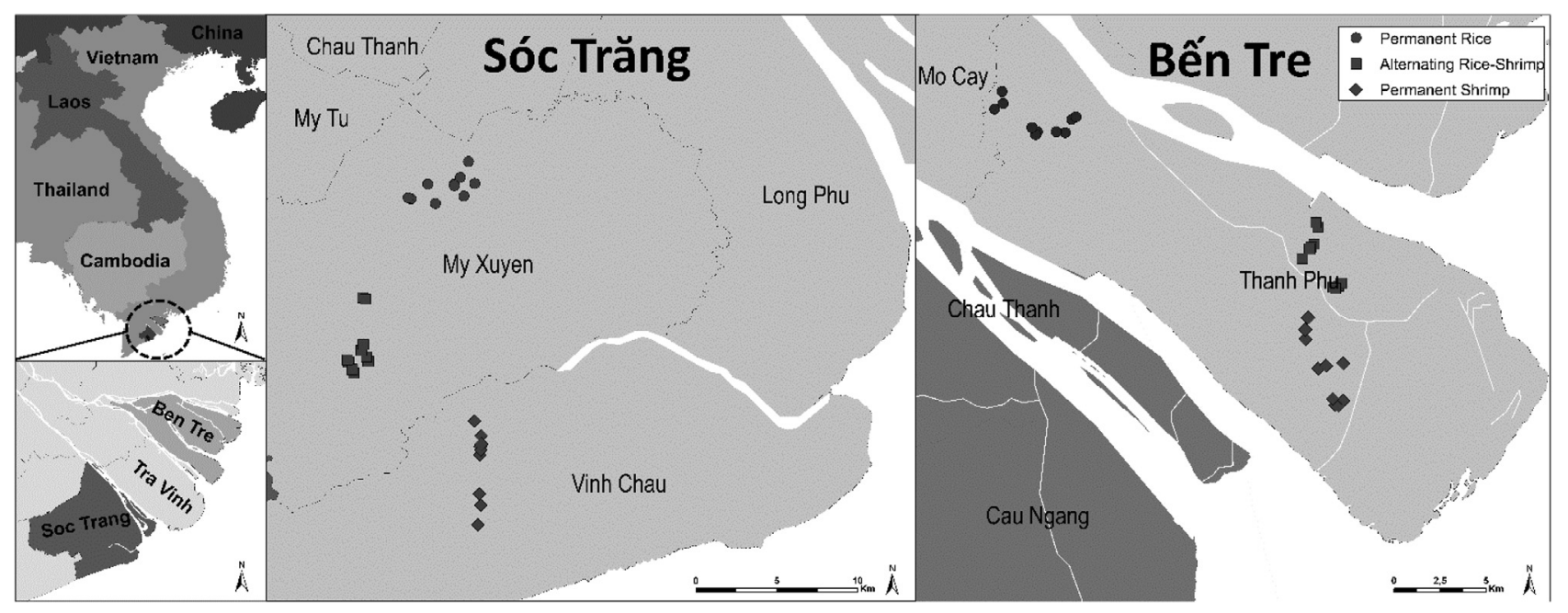

Fig. 2. Overview of sampling sites in Sóc Trăng and B n Tre province, Mekong Delta, Vietnam.

with the alternating rice-shrimp at which the sludge remains during the following rice cropping season. All samples were air dried and sieved to $<2 \mathrm{~mm}$ before further analyses. As this sample preparation procedure may have some effect on the extractability and speciation of elements, direct comparison of results should be limited to investigations using a similar sample preparation.

\subsection{Analysis of basic soil properties}

The texture classes of all samples were assessed directly in the field according to FAO (FAO, 2015), indicating a dominance of silt loam textures at all sites (Table 1 ). All other parameters were analyzed in the lab. The $\mathrm{pH}$ value and electric conductivity $\left(\mathrm{EC}_{2.5}\right)$ was determined in water solution in the ratio of 1:2.5 (Sonmez et al., 2008). Total elemental concentrations of $P\left(P_{t}\right)$, iron $\left(F_{t}\right)$, aluminum $\left(\mathrm{Al}_{\mathrm{t}}\right)$, manganese $\left(\mathrm{Mn}_{\mathrm{t}}\right)$, magnesium $\left(\mathrm{Mg}_{\mathrm{t}}\right)$, potassium $\left(\mathrm{K}_{\mathrm{t}}\right)$, calcium $\left(\mathrm{Ca}_{\mathrm{t}}\right)$, and sodium $\left(\mathrm{Na}_{\mathrm{t}}\right)$ were determined after microwave assisted digestion of $150 \mathrm{mg}$ with $0.7 \mathrm{~mL} \mathrm{HNO}_{3}$ and $2 \mathrm{~mL} \mathrm{HCl} \mathrm{using}$ an inductively coupled plasma-optical emission spectroscopy (ICPOES) (Thermo Fisher iCAP $\left.{ }^{\mathrm{TM}} 7600\right)$. Total nitrogen $\left(\mathrm{N}_{\mathrm{t}}\right)$, carbon $\left(\mathrm{C}_{\mathrm{t}}\right)$, and sulfur $\left(S_{t}\right)$ were determined by dry combustion (MicroCube Elementar, Hanau, Germany), and inorganic $C\left(C_{i}\right)$ was determine by the Scheibler method (DIN ISO 10693). Soil organic carbon (SOC) was calculated by subtracting $C_{i}$ from the $C_{t}$. Ammoniumoxalate extractable phosphorus $\left(\mathrm{P}_{\mathrm{ox}}\right)$ was measured by extraction with $0.2 \mathrm{M}$ ammonium-oxalate and $0.2 \mathrm{M}$ oxalic acid ( $\mathrm{pH} 3.1$ ) for $2 \mathrm{~h}$ in darkness (Schwertmann, 1964) with following detection by ICP-OES.

Effective cation exchange capacity (CEC) was determined using unbuffered $\mathrm{BaCl}_{2}$ as exchanging extracting reagent and subsequent re-exchange of $\mathrm{Ba}^{2+}$ with $\mathrm{Mg}^{2+}$ (Gillman and Sumpter, 1986). Furthermore, obtained $\mathrm{BaCl}_{2}$-extracts were analyzed for total elemental concentrations by ICP-OES to estimate plant available sodium $\left(\mathrm{Na}_{\mathrm{BaCl} 2}\right)$, calcium potassium $\left(\mathrm{K}_{\mathrm{BaCl}}\right)$, calcium $\left(\mathrm{Ca}_{\mathrm{BaCl}}\right)$, and manganese $\left(\mathrm{Mg}_{\mathrm{BaCl}}\right)$, in the sample.

For the time and cost restricted Hedley, XANES and ${ }^{31} \mathrm{P}$ NMRspectroscopy analyses, we pooled the samples from the respective land use systems and compartments within the same province. Therefore, differences were evaluated by trends rather than statistics. Sequential P extraction followed the modified Hedley protocol according to (Tiessen and Moir, 1993) details of the procedure are provided in the Supporting Information. In each duplicate extract, we determined inorganic $\mathrm{P}\left(\mathrm{P}_{\mathrm{i}}\right)$ by the molybdenum-blue method (Murphy and Riley, 1962) using a spectrophotometer (Specord
250 plus; Analytik Jena AG, Germany) and $P_{t}$ by ICP-OES (Thermo Fisher iCAP $\left.{ }^{\mathrm{TM}} 7600\right)$, and organic $\mathrm{P}\left(\mathrm{P}_{\mathrm{o}}\right)$ was calculated as the difference between $P_{t}$ and $P_{i}$. This chemical fractionation recovered between 84 and $101 \%$ of the $\mathrm{P}_{\mathrm{t}}$ (Table $\mathrm{S} 1$, Supporting Information). Non-extractable $P$ (residual-P) was calculated as difference between total $\mathrm{P}$ (aqua regia) and the sum of total $\mathrm{P}$ of all $\mathrm{P}$ fractions.

According to (Negassa and Leinweber, 2009), the obtained fractions can be grouped by their chemical extractability to labile $\mathrm{P}$ (resin- $\mathrm{P}$ and $\mathrm{NaHCO}_{3}-\mathrm{P}_{\mathrm{i}}$ and $-\mathrm{P}_{\mathrm{o}}$ ), moderately labile $\mathrm{P}\left(\mathrm{NaOH}-\mathrm{P}_{\mathrm{i}}\right.$ and $-\mathrm{P}_{\mathrm{o}}$ ) and long-term stable $\mathrm{P}$ including $1 \mathrm{M} \mathrm{HCl}-\mathrm{P}_{\mathrm{i}}$, concentrated $\mathrm{HCl}-\mathrm{P}_{\mathrm{i}}$, and non-extractable-P, highly resistant (residual-P).

Additionally, the $S_{t}$ concentration was determined in all sequentially obtained Hedley extracts to estimate different $\mathrm{S}$ fractions based on their solubility (Lilienfein et al., 2000). The chemical fractionation recovered between 49 and $92 \%$ of $S_{t}$ (Table S3, Supporting Information). However, this procedure does not allow to distinguish between organically and inorganically bound-S as done for P.

For ${ }^{31} \mathrm{P}$ NMR analyses, $7.5 \mathrm{~g}$ of sieved soil $(<2 \mathrm{~mm})$ were shaken vertically $\left(150 \mathrm{rpm} \mathrm{min}^{-1}\right.$ ) for $4 \mathrm{~h}$ in $0.25 \mathrm{M} \mathrm{NaOH} 0.05 \mathrm{M}$ EDTA solution (soil to solution mass ratio $1: 20, \mathrm{pH} \geq 13$ ) at $20^{\circ} \mathrm{C}$ room temperature (Cade-Menun and Preston, 1996). After centrifugation $(10,000 \mathrm{~g} \times 30 \mathrm{~min})$, the supernatant was decanted, frozen at $18^{\circ} \mathrm{C}$ and subsequently lyophilized (Christ BETA 1-8 LDplus). Subsamples of the supernatant were analyzed for $\mathrm{P}_{t}$ and the concentration of paramagnetic ions $\left(\mathrm{Fe}_{\mathrm{t}}, \mathrm{Al}_{\mathrm{t}}\right.$, and $\mathrm{Mn}_{\mathrm{t}}$ ) via ICP-OES (Thermo Fisher ${ }_{i C A P}{ }^{\mathrm{TM}}$ 7600). The $\mathrm{P}_{\mathrm{i}}$ concentrations in the NaOH-EDTA extracts were analyzed via molybdenum-blue method (Murphy and riley, 1962) using a UV-Spectrometer (Specord 250 plus; Analytik Jena AG, Germany). The $\mathrm{P}_{\mathrm{o}}$ concentrations ( $\mathrm{P}_{\mathrm{o}} \mathrm{NaOH}$-EDTA) were calculated by subtraction of $\mathrm{P}_{\mathrm{t}} \mathrm{NaOH}-\mathrm{EDTA}$ by $\mathrm{P}_{\mathrm{i}} \mathrm{NaOH}-\mathrm{EDTA}$.

The NMR-spectra of re-dissolved extracts were recorded at a Bruker 600 Advance NMR-Spectrometer (details of the procedure are provided in the Supporting Information). Due to the low $P$ and high $\mathrm{Fe}$ and $\mathrm{Mn}$ concentrations in the $\mathrm{NaOH}$-EDTA extracts it was not possible to identify individual $\mathrm{P}_{\mathrm{o}}$ compounds. Therefore, we grouped the spectral regions into compound classes based on regions defined in the literature (e.g., (Cade-Menun et al., 2010; Doolette et al., 2009; Turner et al., 2012). For this, spectra from $10 \mathrm{ppm}$ to $-5 \mathrm{ppm}$ were separated into orthophosphate region (6.2 to $5.8 \mathrm{ppm}$ ), the monoester region (7 ppm to 6.2 and 5.8 to $2.5 \mathrm{ppm}$ ), the diester region ( 2.5 to $-3 \mathrm{ppm})$, and the pyrophosphate region ( -3.5 to $-5 \mathrm{ppm})$, referenced by standardizing the 
Table 1

Mean physical and chemical characteristics with standard deviation $(n=10$, respectively for all systems) of samples from three different agricultural land use systems.

\begin{tabular}{|c|c|c|c|c|c|c|c|c|c|c|c|c|}
\hline \multirow{3}{*}{$\begin{array}{l}\text { Province } \\
\text { System } \\
\text { Sampling position }\end{array}$} & \multicolumn{4}{|c|}{ Sóc Trăng } & & & \multicolumn{4}{|c|}{ B n Tre } & & \\
\hline & \multirow{2}{*}{$\begin{array}{l}\text { Permanent Rice } \\
\text { Soil }\end{array}$} & \multicolumn{3}{|c|}{ Alternating Rice-Shrimp } & \multicolumn{2}{|c|}{ Permanent Shrimp } & \multirow{2}{*}{$\begin{array}{l}\text { Permanent Rice } \\
\text { Soil }\end{array}$} & \multicolumn{3}{|c|}{ Alternating Rice-Shrimp } & \multicolumn{2}{|c|}{ Permanent Shrimp } \\
\hline & & Platform & Ditch & Sludge & Soil & Sludge & & Platform & Ditch & Sludge & Soil & Sludge \\
\hline Texture (FAO) & SiL & SiL & SiL & SiL & $\mathrm{SiCL}$ & $\mathrm{SiL}$ & SiCL & $\mathrm{SiL}$ & SiL & SiL & $\mathrm{SiL} / \mathrm{L}$ & SiL \\
\hline $\mathrm{EC}_{2.5}(\mathrm{dS} / \mathrm{m})$ & $1.5 \pm 0.8$ & $2.9 \pm 1.3^{*+}$ & $\S 1.5 \pm 0.1^{\#}$ & 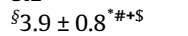 & $\xi_{2.8} \pm 0.6^{* \#}$ & $7.4 \pm 2.2^{* \# S}$ & $1.6 \pm 0.5$ & $\S_{7.3 \pm 1.7^{*+}}$ & $\S_{5.8 \pm 0.8^{* \#}}$ & $\S_{8.6 \pm 1.4^{* \#+}+}$ & $\S_{3.7 \pm 0.8^{* \#}}$ & $7.1 \pm 1.7^{* \#}$ \\
\hline $\mathrm{pH}_{\mathrm{H} 2 \mathrm{O}}$ & $5.2 \pm 0.3$ & $\S_{5.9 \pm 1^{+}}$ & 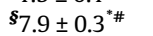 & $\S_{6.8} \pm 0.8^{* \#+\$}$ & $\S_{7.9 \pm 0.3^{*}}$ & $7.9 \pm 0.2^{*} \mathrm{~s}$ & $5.3 \pm 0.2$ & $\S_{3.9 \pm 0.4^{*}}$ & $\S_{4.1 \pm 0.8^{*}}$ & $\S_{4} \pm 0.3^{* \$}$ & $\S_{7.1 \pm 0.5^{* \#}}$ & $7.8 \pm 0.3^{* \# \mathrm{~S}}$ \\
\hline \multicolumn{13}{|c|}{ Total elemental concentrations } \\
\hline $\mathrm{C}_{\mathrm{org}}\left(\mathrm{g} \mathrm{kg}^{-1}\right)$ & $\S_{12.4} \pm 4.1$ & $18.1 \pm 10.2^{+}$ & $\S_{3.6 \pm 0.6^{* \#}}$ & $\S_{12.1} \pm 3.8^{\#+}$ & $\S_{4.5 \pm 0.9^{* \#}}$ & $9.8 \pm 2.4^{\#}$ & $\S_{18.6 \pm 5.7}$ & $20.9 \pm 3.9$ & $\S_{16.3 \pm 4.9^{\#}}$ & 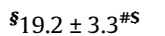 & 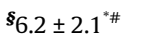 & $8.5 \pm 3.1^{* \# \$}$ \\
\hline$C_{\text {inorg }}\left(\mathrm{g} \mathrm{kg}^{-1}\right)$ & $0 \pm 0$ & $s_{0.2 \pm 0.2^{*+}}$ & $0 \pm 0^{\#}$ & $s_{0.4 \pm 0.2^{*} \#+\$}$ & $0.2 \pm 0.1^{* \#}$ & $1.6 \pm 0.7^{*} \# \mathrm{~S}$ & $0 \pm 0$ & $\S_{0} \pm 0^{+}$ & $0 \pm 0^{\#}$ & $\S_{0.1 \pm 0^{*} \#+\$}$ & $0.4 \pm 0.3^{* \#}$ & $2.2 \pm 1.5^{* \# \mathrm{~S}}$ \\
\hline $\begin{array}{l}N_{\mathrm{t}}\left(\mathrm{g} \mathrm{kg}^{-1}\right) \\
n^{-1}\end{array}$ & $\$_{1.4 \pm 0.4}$ & $1.9 \pm 0.6^{*+}$ & 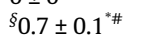 & $1.5 \pm 0.3^{\#+}$ & $0.8 \pm 0.1^{* \#}$ & $s_{1.4 \pm 0.2^{\#}}$ & $\xi_{1.8} \pm 0.4$ & $1.9 \pm 0.2^{+}$ & $s_{1.2} \pm 0.3^{*} \#$ & $1.7 \pm 0.2^{\#+S}$ & $0.8 \pm 0.2^{*} \#$ & $\S_{1} \pm 0.3^{* \# \$}$ \\
\hline $\begin{array}{l}\mathrm{C} / \mathrm{N} \\
\mathrm{t}\end{array}$ & $\S_{8.8 \pm 1.2}$ & $\S_{9.2 \pm 1.8^{+}}$ & 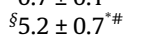 & $\S_{8} \pm 1^{* *+}$ & $s_{6} \pm 0.8^{*}$ & $\S_{8.3} \pm 0.9$ & $s_{10.3 \pm 1}$ & $\boldsymbol{s}_{10.9 \pm 1.3}$ & 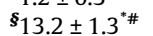 & $s_{11.1 \pm 1.1^{\#}}$ & $\S_{8.4 \pm 0.9^{* \#}}$ & $s_{10.7 \pm 2.4^{\#}}$ \\
\hline $\mathrm{S}_{\mathrm{t}}\left(\mathrm{g} \mathrm{kg}^{-1}\right)$ & $s_{0.4} \pm 0.2$ & $\S_{3.5} \pm 2.9^{*}$ & $\S_{0.3 \pm 0.2^{\#}}$ & $\xi_{2.4} \pm 1.3^{*} \#$ & $\S_{0.3 \pm 0.1^{\#}}$ & $2.4 \pm 1.5^{* \#}$ & $s_{0.8 \pm 0.2}$ & $s_{10.4 \pm 4.5^{*+}}$ & $s_{12.3 \pm 4.4^{*}}$ & $s_{13} \pm 3.7^{*+s}$ & $\S_{2.2 \pm 1.1^{*}}$ & $2.3 \pm 0.7^{* \$}$ \\
\hline $\mathrm{Fe}_{(}\left(\mathrm{g} \mathrm{kg}^{-1}\right)$ & $29.4 \pm 5.5$ & $30.3 \pm 4.9^{+}$ & 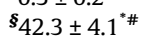 & $35.7 \pm 2.3^{* \#+}$ & $\S_{42} \pm 4.5^{*} \#$ & $34.8 \pm 2.7^{* \#}$ & $22.9 \pm 8.6$ & $31.7 \pm 2.8^{*+}$ & $\S 34.7 \pm 4.4^{*}$ & $34.9 \pm 2.2^{*+}$ & $\S_{33.8 \pm 5.4^{*}}$ & $35.4 \pm 8.3^{*}$ \\
\hline $\mathrm{Ca}_{\mathrm{t}}\left(\mathrm{g} \mathrm{kg}^{-1}\right)$ & $\S_{0.7 \pm 0.2}$ & $\xi_{2.2} \pm 1.2^{*}$ & $1.9 \pm 0.5^{* \#}$ & $s_{3} \pm 1^{* * \# s}$ & $2.2 \pm 0.8^{* \#}$ & $8 \pm 2.9^{* * 1}$ & $\S_{1.3 \pm 0.3}$ & $\xi_{1.3 \pm 0.3^{+}}$ & $1.7 \pm 0.4^{*}$ & $\S_{1.8} \pm 0.3^{*+\$}$ & $2.9 \pm 3^{* \#}$ & $11.4 \pm 7.5^{*} \# \mathrm{~S}$ \\
\hline $\mathrm{Mg}_{\mathrm{t}}\left(\mathrm{g} \mathrm{kg}^{-1}\right)$ & $2.9 \pm 0.5$ & $\S_{4.5} \pm 0.2^{*+}$ & 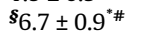 & 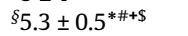 & $s_{6.3 \pm 0.3^{* \#}}$ & $\boldsymbol{s}_{6.8 \pm 0.5^{*} \# \mathrm{~s}}$ & $3.1 \pm 0.5$ & $\S_{5.3 \pm 0.6^{*+}}$ & $\S_{5.7 \pm 0.9^{*}}$ & $s_{6} \pm 0.4^{*+}$ & $\S_{4.9 \pm 0.7^{* \#}}$ & $\S_{5.5} \pm 1.2^{* \#}$ \\
\hline $\mathrm{K}_{\mathrm{t}}\left(\mathrm{g} \mathrm{kg}^{-1}\right)$ & $2.1 \pm 0.7$ & $\S_{3.5 \pm 0.4^{*}}$ & $\S_{3.2} \pm 0.3^{*}$ & $s_{3.2} \pm 0.7^{*}$ & $s_{2.9 \pm 0.2^{* \#}}$ & $s_{3.4 \pm 0.3^{*} \#}$ & $2.4 \pm 0.6$ & $\S_{2.2} \pm 0.3^{+}$ & $\S_{2.3} \pm 0.6^{\#}$ & $\xi_{2.7} \pm 0.2^{\#+}$ & $\xi_{2.2} \pm 0.4$ & $\delta_{2.3 \pm 0.6}$ \\
\hline $\mathrm{P}_{\mathrm{t}}\left(\mathrm{mg} \mathrm{kg}^{-1}\right)$ & $411 \pm 52$ & $\S_{304 \pm 54^{*+}}$ & $\S_{586 \pm 95^{* \#}}$ & $\S_{523} \pm 53^{* \#+\$}$ & $s_{622 \pm 89^{*}}$ & $681 \pm 155^{* \mathrm{~s}}$ & $339 \pm 112$ & $\S_{356 \pm 46^{+}}$ & $\S_{384 \pm 69^{\#}}$ & 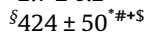 & $\S_{496 \pm 92^{* \#}}$ & $734 \pm 215^{* \# S}$ \\
\hline $\mathrm{Zn}_{\mathrm{t}}\left(\mathrm{mg} \mathrm{kg}^{-1}\right)$ & $53 \pm 8$ & $\S_{63} \pm 4^{*+}$ & $\S_{84} \pm 5^{* \#}$ & $\S_{68} \pm 4^{* \#+\$}$ & $\S_{78 \pm 5^{*}}$ & $\S_{77 \pm 4^{*} \mathrm{~s}}$ & $47 \pm 11$ & $s_{68 \pm 6^{*}}$ & $\S_{70 \pm 9^{* \#}}$ & $s_{77 \pm 4^{*} \# \mathrm{~s}}$ & $\S_{65} \pm 8^{*}$ & $\S_{68} \pm 10^{* \$}$ \\
\hline \multicolumn{13}{|c|}{ Plant available mutrient elements } \\
\hline $\operatorname{CEC}\left(\mathrm{cmol}^{+} \mathrm{kg}^{-1}\right)$ & $13.7 \pm 3.6$ & $\S_{21.2} \pm 1.5^{*+}$ & $\S_{23.5 \pm 1^{*} \#}$ & $\S_{21.9 \pm 1.2^{* \#+}}$ & $\S_{22.3 \pm 0.7^{*}}$ & $\S_{22.1 \pm 0.7^{*}}$ & $16.1 \pm 2.5$ & $\S_{14.6 \pm 1.4^{+}}$ & $\S_{13.7 \pm 2.2^{*}}$ & 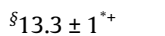 & $s_{14.9 \pm 3.4}$ & $\S_{15.1 \pm 3.7}$ \\
\hline $\mathrm{Ca}_{\mathrm{BaCl}}\left(\mathrm{mg} \mathrm{kg}^{-1}\right)$ & $\S_{655 \pm 192}$ & $\S_{1081 \pm 187^{*}}$ & 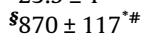 & $\S_{1198} \pm 354^{* \# \$}$ & $976 \pm 204^{* \#}$ & $1423 \pm 286^{*} \# \mathrm{~S}$ & $\S_{1132} \pm 218$ & $\S_{469 \pm 99^{*}}$ & $\S_{546} \pm 159^{*}$ & $\$ 550 \pm 126^{* \$}$ & $733 \pm 384^{* \#}$ & $1275 \pm 522^{\# \mathrm{~S}}$ \\
\hline $\mathrm{K}_{\mathrm{BaCl} 2}\left(\mathrm{mg} \mathrm{kg}^{-1}\right)$ & $297 \pm 119$ & $s_{660 \pm 61^{*}}$ & $s_{563 \pm 75^{*} \#}$ & $s_{678 \pm 41^{* \# \$}}$ & $s_{658 \pm 72^{* \#}}$ & 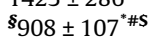 & $285 \pm 68$ & $\S_{278} \pm 167$ & $\S 178 \pm 186$ & $\S_{227 \pm 170^{\$}}$ & $\S_{545 \pm 96^{* \#}}$ & $\S_{580} \pm 108^{*} \# \mathrm{~S}$ \\
\hline $\mathrm{Na}_{\mathrm{Ba} 212}\left(\mathrm{~g} \mathrm{~kg}^{-1}\right)$ & $0.9 \pm 0.3$ & $\S_{1.7 \pm 0.4^{*}}$ & $1.6 \pm 0.1^{* \#}$ & $\S_{1} .9 \pm 0.2^{* \# \$}$ & $\S_{2.2 \pm 0.3^{* \#}}$ & $3.5 \pm 1^{* \# S}$ & $0.9 \pm 0.2$ & $\S_{2.9 \pm 0.6^{*+}}$ & $1.6 \pm 0.5^{* \#}$ & $\S_{3.6 \pm 0.6^{* \#+}}$ & $\xi_{1.8 \pm 0.2^{* \#}}$ & $3 \pm 0.7^{* \#}$ \\
\hline $\mathrm{Mg}_{\mathrm{B} 2 \mathrm{Cl} 2}\left(\mathrm{~g} \mathrm{~kg}^{-1}\right)$ & $0.9 \pm 0.2$ & $1.4 \pm 0.2^{*}$ & $1.4 \pm 0.1^{* \#}$ & $1.5 \pm 0.1^{*} \#$ & $s_{1.2 \pm 0 * \#}$ & 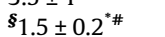 & $1 \pm 0.1$ & $1.3 \pm 0.3^{*+}$ & $1.4 \pm 0.2^{*}$ & $1.5 \pm 0.2^{*}+5$ & $\S_{0.9 \pm 0.2}$ & $\xi_{1} \pm 0.2^{\$}$ \\
\hline $\mathrm{P}_{\mathrm{ox}}\left(\mathrm{mg} \mathrm{kg}^{-1}\right)$ & $\S_{162 \pm 60}$ & $\S_{100 \pm 39^{*+}}$ & $219 \pm 68^{\#}$ & 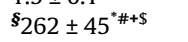 & $208 \pm 31^{* \#}$ & $336 \pm 100^{* \# \mathrm{~S}}$ & $s_{66} \pm 39$ & $\S_{165} \pm 38^{*+}$ & $209 \pm 60^{*}$ & $\S_{208} \pm 49^{*}+\$$ & $288 \pm 95^{* \#}$ & $389 \pm 134^{*} \# \mathrm{~S}$ \\
\hline
\end{tabular}

\section{$\mathrm{CEC}=$ cation exchange capacity}

$P_{\text {ox }}=$ Ammonium-oxalate extractable phosphorus.

Indices on the left side indicate comparisons between both provinces, indices on the right between land use systems or subdomains within the same province. Indices in bold indicate the respective higher value:

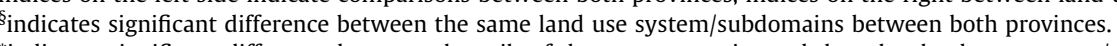

indicates significant difference between the soils of the permanent rice and the other land use systems/subdomains with the respective province.

"indicates significant difference between sludge and the soil underneath within the same land use system and province (paired samples).

indicates significant difference between platform and the sludges in the in the alternating rice-shrimp systems for each province (paired samples).

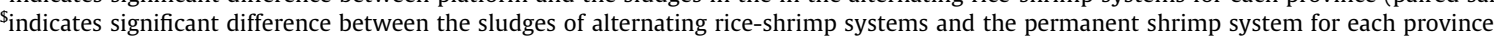


orthophosphate peak to $6 \mathrm{ppm}$. The peak areas in each of these regions were summarized and the total percentage of each of these four regions was calculated. The NMR spectra of all three land use systems can be found in the Supporting Information.

Bulk P and S K-edge XANES spectra were recorded at the Soft Xray Micro-characterization Beamline (SXRMB) at the Canadian Light Source synchrotron, Saskatoon, Canada (Hu et al., 2010). Details of the sample preparation and subsequent data treatment are provided in the Supporting Information. Base on the S XANES fitting results, obtained proportions of different $S$ reference compounds and associated S oxidation states were grouped into three major groups according to (Solomon et al., 2003) namely (i) reduced $\mathrm{S}$ forms (disulfides, thiols, thiophenes), (ii) intermediate oxidized S forms (sulfoxides, sulfones, sulfonates), and (iv) highly oxidized S forms (sulfates).

\subsection{Statistics}

All statistical analyses were done using IBM $^{\circledR}$ SPSS $^{\circledR}$ Statistics Version 25. To test for significant differences between sample groups, data were first tested for normal distribution via a Shapiro-Wilk-test $(P<0.05)$. If the data sets were normally distributed and showed an equal variance (Levene test), a $t$-test was applied. If the set showed a normal distribution but no equal variance, the Welch-test was conducted. In case of non-normal distribution, the Mann-Whitney-Rank-Sum-test was applied for comparison. For comparison of dependent sample groups, (e.g., sludge $v s$. soil underneath and platform $v$ s. sludge) a paired $t$-test was used if the data were normal distributed and Wilcoxon signed rank test if data showed a non-normal distribution.

\section{Results}

\subsection{Basic soil characteristics}

As salinity is important for soil fertility, we first assessed the $\mathrm{EC}_{2.5}$ values. They were lowest in the permanent rice systems (Table 1). Among both shrimps systems, $\mathrm{EC}_{2.5}$ values varied being, with generally higher in the sludge than in to the soil underneath. Among sampled compartments and systems, highest $\mathrm{EC}_{2.5}$ values were found for the alternating rice-shrimp systems in $\mathrm{B} n$ Tre (Table 1 ). The soils of the permanent shrimp systems were generally characterized by $\sim 2$ times higher $\mathrm{EC}_{2.5}$ values than the soil of all permanent rice system and the soil obtained from the platform from Sóc Trăng, whereas no difference were found for the ditch/ soil. By contrast, $\mathrm{EC}_{2.5}$ values of the ditch/soil in Ben Tre were $\sim 4$ times higher and platform/soil $\sim 5$ times higher as in the permanent rice.

These differences were not accompanied by different $\mathrm{pH}$ values, which were similar for the permanent rice systems $(\mathrm{pH}=5.2$ to 5.3) and slightly alkaline for the systems including shrimps. An exception were the rice-shrimp systems in B $\mathrm{n}$ Tre, which were even more acidic than the permanent rice systems (Table 1 ). In addition, the $\mathrm{pH}$ of the sludge in the rice-shrimp system was always more acidic than the permanent shrimp sludge (6.8 vs. 7.9).

In any case, already these few data indicate that land use effects on some soil properties were different among provinces, i.e., they were site-specific. Soil fertility indicators such as the concentrations of $\mathrm{N}_{\mathrm{t}}$, plant-available nutrients, and CEC generally pointed to similar or improved nutrient status in the alternating rice-shrimp and permanent shrimp systems compared to the permanent rice systems. An exception to this was the available Ca concentration, which was depleted when the soil had become more acidic, such as in the alternating rice-shrimp systems of $\mathrm{B} \mathrm{n}$ Tre (Table 1). In addition, the total element concentrations were mostly enriched in the alternating rice-shrimp and permanent shrimp systems relative to the systems under permanent rice. Highest enrichments were found for $\mathrm{P}_{\mathrm{t}}, \mathrm{Ca}_{\mathrm{t}}$, and available $\mathrm{Ca}$ and $\mathrm{K}$ in soils and sludges of the permanent shrimp systems. Soils underneath the sludge from both shrimp systems were depleted in SOC and $\mathrm{N}_{\mathrm{t}}$ relative to the permanent rice systems. By contrast, sludges of the alternating rice-shrimp system showed similar concentrations in SOC and $\mathrm{N}_{\mathrm{t}}$ relative to the permanent rice whereas for the permanent shrimp system SOC and $\mathrm{N}_{t}$ concentration were depleted (Table 1).

The effects of shrimp cultivation were obvious for the $S_{t}$ concentrations especially in Sóc Trăng, which were elevated by a factor of six in the sludges of both shrimp systems and by a factor of nine in the platform of the rice-shrimp system. In $B \mathrm{n}$ Tre $\mathrm{S}_{\mathrm{t}}$ concentrations were generally higher as in Sóc Trăng particularly for all compartments of the alternating shrimp. No such enrichment was usually found for the soils underneath the sludges, with again one exception tor B $\mathrm{n}$ Tre (Table 1

\subsection{Sequential phosphorus and sulfur fractionation}

As $\mathrm{P}$ is a key element limiting soil fertility for plants, we performed a sequential extraction to highlight $P$ pools of different availability. In all samples, the analyses identified only minor proportions of readily plant-available, resin-P (2 to 4\%). Proportions of $\mathrm{NaHCO}_{3}-\mathrm{P}_{\mathrm{i}}$ did not vary significantly between land use systems and were also rather low (2 to 6\%). Main differences in P forms were thus mainly found for the less easily extractable and thus more stable $\mathrm{P}$ pools. The concentrations of $\mathrm{NaHCO}_{3}-\mathrm{P}_{0}$, for instance, already contributed to 2 to $29 \%$ of total P; with highest values found in the permanent rice systems in Sóc Trăng and riceshrimp sludge in B $\mathrm{n}$ Tre (Table S1, Supporting Information).

The $\mathrm{NaOH}$-extractable $\mathrm{P}$ proportions decreased in the order: rice-shrimp/platform $>$ rice-shrimp/sludge $>$ permanent shrimp/ sludge > permanent shrimp/soil > rice-shrimp/ditch; only in B $n$ Tre this order was different due to the higher proportions in the sludges of the rice-shrimp systems and the soils underneath. Inorganic $\mathrm{P}_{\mathrm{i}}$ dominated in these $\mathrm{NaOH}$-extracts. An even larger proportion of $\mathrm{P}_{\mathrm{t}}$ could be assigned to the two $\mathrm{HCl}_{1 \mathrm{M}}$ fractions, which together comprised up to $70 \%$ of $\mathrm{P}_{\mathrm{t}}$. Under permanent rice, the $\mathrm{HCl}_{\text {conc }}-\mathrm{P}$ fraction were 4 to 5 -fold higher than those of $1 \mathrm{M} \mathrm{HCl}$ $\mathrm{P}$, although the proportions of $\mathrm{HCl}-\mathrm{P}$ were significantly lower (8 to $11 \%$ of $\mathrm{P}_{t}$ ) in permanent rice system than in the alternating rice-shrimp or permanent shrimp systems ( 14 to $42 \%$ of $\mathrm{P}_{\mathrm{t}}$ ).

Between 0 and $16 \%$ of $\mathrm{P}_{t}$ remained in the residual pools (Table S1; Supporting Information). When pooling the absolute concentrations within commonly operative defined P-pools for a better visualization (Fig. 3, left), it can be seen that the concentration of stable and residual-P in the permanent rice systems were lower than in all other tested land use systems with highest values be found for soil (Sóc Trăng) and sludge (B n Tre). In the permanent shrimp and alternating rice-shrimp systems, concentrations of labile + moderate labile-P were lower than for permanent rice and increased in the order (platform) $>$ ditch $>$ sludge despite differences in $\mathrm{P}_{\mathrm{t}}$, expect for both sludges rom $\mathrm{B} \mathrm{n}$ Tre with almost identically concentrations ( $195 \mathrm{mg} \mathrm{kg}^{-1}$ ) that were both $\sim 40 \%$ higher than in the permanent rice.

Sulfur showed a different distribution pattern within the sequential fractions than P did (Table S2; Supporting Information). The largest proportions of extractable $S$ were always found in the $\mathrm{H}_{2} \mathrm{O}+$ Resin-S fraction, except for all sampled compartments of the alternating rice-shrimp system in $\mathrm{B} \mathrm{n}$ Tre, where the highest proportions of $\mathrm{S}_{\mathrm{t}}$ were found in the $\mathrm{NaOH}$ fraction (Table S2; Supporting Information). Furthermore, there was a consistent $\sim 2$-fold higher proportions of $\mathrm{NaOH}$ extractable-S in the permanent rice systems relative to the permanent shrimp ones, which, in turn, 

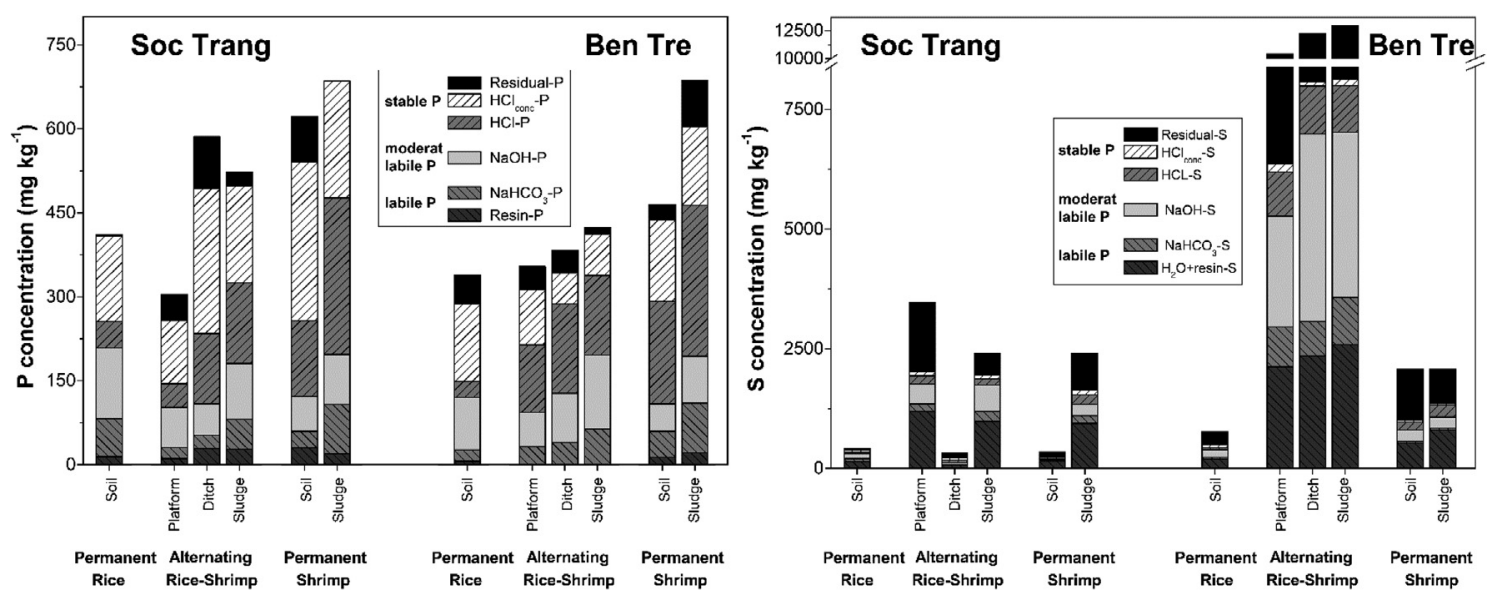

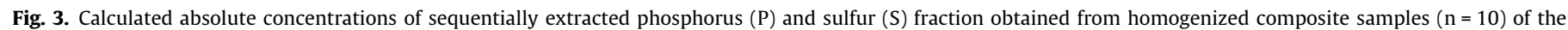

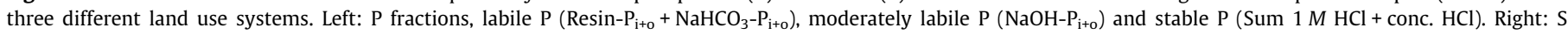
fractions: labile $\mathrm{S}\left(\right.$ Resin- $\left.\mathrm{S}_{\mathrm{t}}+\mathrm{NaHCO}_{3}-\mathrm{S}_{\mathrm{t}}\right)$, moderately labile $\mathrm{S}\left(\mathrm{NaOH}-\mathrm{S}_{\mathrm{t}}\right)$ and stable $\mathrm{P}(\mathrm{Sum} 1 \mathrm{M} \mathrm{HCl}+\mathrm{conc}$. $\mathrm{HCl}+$ residual-P).

Table 2

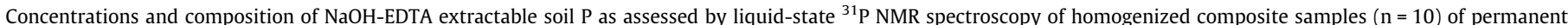

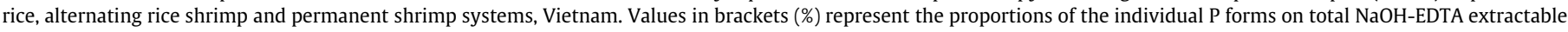
soil P.

\begin{tabular}{|c|c|c|c|c|c|c|c|c|}
\hline \multirow[t]{2}{*}{ Province } & \multicolumn{2}{|c|}{$\begin{array}{l}\text { Land use system/Sample } \\
\text { position }\end{array}$} & \multirow{2}{*}{$\begin{array}{l}\text { P-recovery } \mathrm{NaOH}- \\
\text { EDTA extracts } \\
\% \text { of total P }\end{array}$} & \multirow[t]{2}{*}{$\begin{array}{l}\text { Orthophosphate } 6.2 \\
\text { to } 5.8 \mathrm{ppm}\end{array}$} & \multirow[t]{2}{*}{$\begin{array}{l}\text { P-Monoesters } 7 \\
\text { to } 2.5 \mathrm{ppm}\end{array}$} & \multirow{2}{*}{$\begin{array}{l}\text { P-Diesters } 2.5 \\
\text { to }-3 \mathrm{ppm} \\
\mathrm{mg} \mathrm{kg}^{-1}(\%)\end{array}$} & \multirow[t]{2}{*}{$\begin{array}{l}\text { Pyrophosphate }-3.5 \\
\text { to }-5 \mathrm{ppm}\end{array}$} & \multirow[t]{2}{*}{$\begin{array}{l}\text { P-mono-to } \\
\text { P-diester ratio }\end{array}$} \\
\hline & & & & & & & & \\
\hline Sóc Tra & Permanent Rice & & 45 & $161(87)$ & $16(9)$ & $5(3)$ & $2(1)$ & 3 \\
\hline \multirow[t]{5}{*}{ ng } & Alternating & Platform & 35 & $85(79)$ & $15(14)$ & $5(5)$ & $2(1)$ & 3 \\
\hline & Rice-Shrimp & Ditch & 22 & $107(90)$ & $5(4)$ & $5(4)$ & $2(1)$ & 1 \\
\hline & & Sludge & 40 & $164(79)$ & $37(18)$ & $6(3)$ & $2(1)$ & 6 \\
\hline & Permanent & Soil & 20 & $126(91)$ & $5(4)$ & $5(4)$ & $2(1)$ & 1 \\
\hline & Shrimp & Sludge & 50 & 317 (93) & $16(5)$ & $5(2)$ & $2(1)$ & 3 \\
\hline \multirow[t]{6}{*}{ B n Tre } & Permanent Rice & & 44 & $123(82)$ & $19(12)$ & $5(4)$ & $2(2)$ & 3 \\
\hline & Alternating & Platform & 37 & $82(63)$ & 39 (29) & $8(6)$ & $2(1)$ & 5 \\
\hline & Rice-Shrimp & Ditch & 36 & $114(82)$ & $15(11)$ & $7(5)$ & $2(1)$ & 2 \\
\hline & & Sludge & 42 & $150(84)$ & $20(11)$ & $6(4)$ & $2(1)$ & 3 \\
\hline & Permanent & Soil & 25 & $103(88)$ & $6(5)$ & $5(4)$ & $2(2)$ & 1 \\
\hline & Shrimp & Sludge & 41 & $258(92)$ & $14(5)$ & $5(2)$ & $2(1)$ & 2 \\
\hline
\end{tabular}

tended to be enriched in residual-S. In general, the concentrations of $\mathrm{S}$ pools in these sludges of the permanent shrimp farms increased in the order $\mathrm{HCl}_{\mathrm{con}^{-}}-\mathrm{S}<\mathrm{NaHCO}_{3}-\mathrm{S}<\mathrm{HCl}_{1 \mathrm{M}}-\mathrm{S}<\mathrm{NaOH}-$ $\mathrm{S}<\mathrm{H}_{2} \mathrm{O}+$ Resin-S, whereas for the rice-shrimp systems in B $\mathrm{n}$ Tre the order of $\mathrm{NaOH}-\mathrm{S}$ and $\mathrm{H}_{2} \mathrm{O}+$ Resin-S were exchanged. A slight different but consistent order was found for the soils underneath the sludges of both shrimp influenced systems following the order $\mathrm{NaHCO}_{3}-\mathrm{S}<\mathrm{HCl}_{\text {con }}-\mathrm{S}<\mathrm{NaOH}-\mathrm{S}<\mathrm{HCl}_{1 \mathrm{M}}-\mathrm{S} \leq \mathrm{H}_{2} \mathrm{O}+$ Resin-S. Again, the samples from rice-shrimp was an exception with a slightly modified order (Table S3; Supporting Information), which we attribute to the extraordinary large $S_{t}$ concentrations and differences in the origin of the $\mathrm{S}$ in the soil in $\mathrm{B} \mathrm{n}$ Tre. As a result, differences among land use systems were consequently even more reflected in the absolute concentrations of individual S-fractions than by mere percentage values (Fig. 3 , right).

\section{3. $P$ bonding forms (NMR and XANES analyses)}

To get a better insight into soil organic P (SOP) binding forms, we performed ${ }^{31} \mathrm{P}$ NMR analyses after sample extraction with $\mathrm{NaOH}-\mathrm{EDTA}$ mixtures. This extraction recovered between 52 and $77 \%$ of total organic $\mathrm{P}$ (Table 2 ), without differences among regions, but with higher $P$ recoveries of the sludges than of the soil underneath. Hence, we cannot exclude the possibility that the assessment of the SOP composition of the sludges was slightly biased by improved extractability. In all agricultural land use systems, the largest proportions of NaOH-EDTA extractable P were in the form of orthophosphates. Pyrophosphates, in contrast, occurred only in minor proportions (Table 2). In the majority of the samples, P-monoesters were more abundant than P-diesters, with maximum proportions of monoester-P being recorded for the alternating rice-shrimp systems in both regions. Overall, the proportions of the monoester exceeded those of the diesters by a factor of up to six, resulting in mono to diester ratios of up to 1 to 6 (rice-shrimp/sludge, Sóc Trăng). In both provinces, mono to diester ratios were lowest in the soils beneath the sludges. Whereas, ratios of the permanent rice and both shrimp systems were not different between provinces, mono-to-diester ratios of the three different compartments of rice-shrimp systems varied between provinces with highest values for the sludge in Sóc Tra ng and for the platform in $\mathrm{B} n$ Tre.

\subsection{P K-edge XANES spectroscopy}

While ${ }^{31} \mathrm{P}$ NMR provides information about organic $\mathrm{P}$ forms $\left({ }^{33} \mathrm{~S}-\mathrm{NMR}\right.$ not feasible for liquid soil samples), $\mathrm{P}$ and $\mathrm{S}$ XANES spectroscopy may provide manly information for inorganic $P$ and $S$ speciation. The linear combination fitting of spectra using 11 soil 

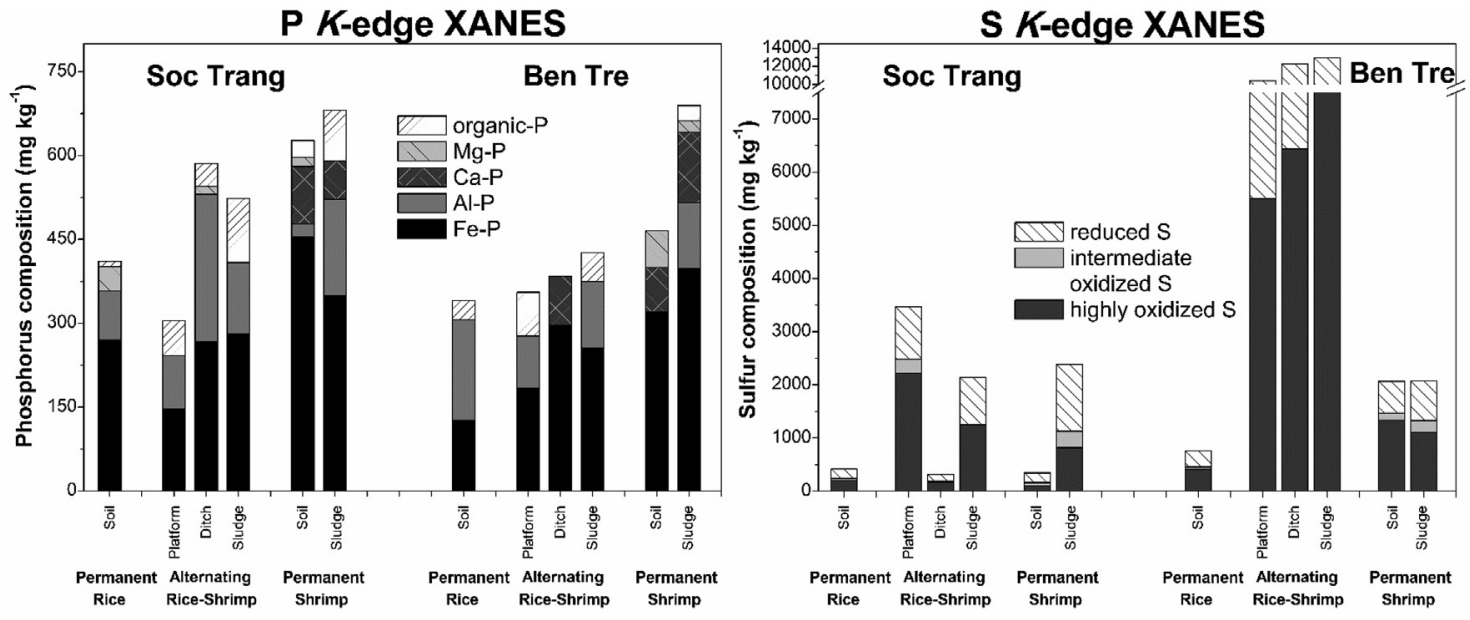

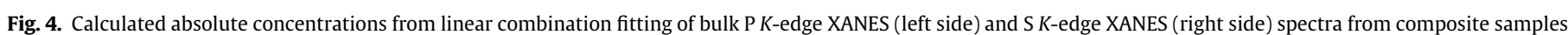

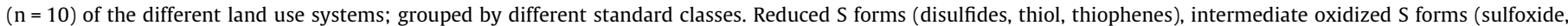
sulfone, sulfonate), and highly oxidized S forms (sulfate).

relevant reference compounds indicated that the overall $\mathrm{P}$ composition at all sites was dominated by $\mathrm{P}$ associated with $\mathrm{Fe}$ or $\mathrm{Al}$ oxides (Fe-P, Al-P), followed by $\mathrm{P}$ associated to $\mathrm{Ca}$ such as apatite (Ca-P), and organic structures (organic-P) (Fig. 4, left, Table S3, Supporting Information). Differences between provinces were not very much pronounced, except that for the permanent rice systems, the less acidic region in Sóc Trăng was characterized by larger proportions of Fe-P and Mg-P but lower portions of Al-P than the sites in B $\mathrm{n}$ Tre. The introduction of shrimp increased the proportions of $P$ in organic form in the uppermost sampled compartments by a factor of 2 to 10 , both in the alternating rice-shrimp and permanent shrimp relative to the permanent rice (Table S3 Supporting Information; Fig. 4 left). This relative increase was more pronounced in Sóc Trăng as the permanent rice systems in B n Tre were already characterized by higher proportions of organic-P compare to Sóc Trăng. In general, proportions of organic-P were always higher in the sludges compared to the soils underneath, in agreement to P fractionation results (Table S1, Supporting Information). Furthermore, portions of Ca-P were only found in all permanent shrimp systems and for the alternating rice-shrimp in B n Tre, but in both provinces not in those under permanent rice management (Table S3, Supporting Information; Fig. 3, left).

The $S$ composition reflected most clearly differences in land use. The permanent rice systems showed no differences between provinces and were dominated by oxidized Fe-sulfates and reduced organic sulfides and; in addition, higher proportions of thiophene S structures (19 to $23 \%$ ) were only detected in these rice systems (Table S3 Supporting Information; Fig. 4, right). The cultivation of shrimps obviously increased the proportion of highly reduced $S$ forms, such as in $\mathrm{FeS}$ and $\mathrm{FeS}_{2}$; except for the permanent shrimp systems in Sóc Trăng, where reduced $S$ forms deceased relative to the permanent rice systems. Oxidized $\mathrm{S}$ forms were also found, but they were associated with Ca rather than with Fe, particularly under permanent shrimp management. However, this seems site specific, since for the rice-shrimp systems in B $\mathrm{n}$ Tre the LCF results hint to the dominance of Fe associated sulfates. Fingerprints of management on the chemical signatures of soils were thus most pronounced for S. (Table S3 Supporting Information; Fig. 3).

\section{Discussions}

Permanent cultivation of paddy rice has a long history in the Southeast Asia and so in the Mekong delta in Vietnam. The long-term soil management results in altered pedogenesis of the soil with defined horizons characterized by specific hydraulic and geochemical properties as reviewed by, e.g., (Kögel-Knabner et al., 2010). The soils under study had silty texture, which explains why, for instance, the Ardp horizons were less clearly developed as, e.g., reported by Kölbl et al. (2014). Nevertheless, basic soil properties and total elemental concentrations were within range of concentrations published elsewhere (e.g., Egashira et al., 2003; Pan et al., 2004), i.e., the soils studied here can be seen as representative for other paddy rice soils of the world. Nevertheless, we noted slight differences among regions: liberation of sulfates in plant available forms likely contributed to more acidic conditions and exposure of (potential) acid sulfate soil layers in B $\mathrm{n}$ Tre compared to Sóc Trăng, going along with higher contents of SOM, Al associated $\mathrm{P}$, and lower contents of $\mathrm{Ca}$ or $\mathrm{Mg}$ associated $\mathrm{P}$, and highlighting the need to keep the soils submerged, particularly when potentially approaching sulfuric horizons.

\subsection{Impact of different land use types on soil properties}

Changes in land management practice often leads to characteristic changes in the bio-geochemical properties of soils. If these changes in land use alter soil fertility irreversibly, it may hinder the farmer to switch back to the former land use with lock-in effects for future decision-making. Here, switching from permanent paddy rice to alternating rice-shrimp or permanent shrimp resulted in an overall salinization of the soil indicated by an increase in electric conductivity $\left(\mathrm{EC}_{2.5}\right)$ and accumulation of e.g., available $\mathrm{Na}$ (Table 1 ), as also reported in various other studies (Das et al., 2017; e.g., Tho et al., 2008). The effects were stronger with increasing intensity of shrimp cultivation (alternating riceshrimp < permanent shrimp) and degree of exposure to shrimps (ditch/soil < platform soil). Furthermore, results from both provinces indicated that shrimp-cultivation not only increased salinity in the uppermost soil layers, but due to downward leaching and incomplete sludge removal also underneath the sludge.

The observed higher salinity levels and concentrations of $\mathrm{Na}_{\mathrm{BaCl} 2}$ in the alternating rice-shrimp systems of $\mathrm{B} n$ Tre when compared with Sóc Trăng are most likely a result of a difference in the sampling time. In $\mathrm{B} n$ Tre the rice at the platform had already been harvested and farmers had already introduced saltwater for shrimp cultivation, while the fields in Sóc Trăng were not yet flooded. This was possibly also influenced by the in general 
more severe salinity problems in B $\mathrm{n}$ Tre, which was especially strong in the sampling year due to the El Niño phenomenon (Vietnam+, 2016).

The elevated concentrations of available $\mathrm{Na}_{\mathrm{BaCl}}$ and salinity values also indicate that one rainy season was insufficient to completely flush out the salts from the platform soil of the rice-shrimp system. Taking the $\mathrm{Na}_{\mathrm{BaCl} 2}$ concentrations from the permanent rice systems (mean $923 \mathrm{mg} \mathrm{kg}^{-1}$ ) as baseline, $\mathrm{Na}_{\mathrm{BaCl} 2}$ contents increased by a factor of around two in the platform and ditch soil of the rice-shrimp farms as well as in the soil beneath the sludge in the permanent shrimp systems. Altered availability or even losses of other essential nutrients by competitive sorption and subsequent leaching as well as reduced plant uptake by increased osmotic pressure is thus likely (Fageria et al., 2011).

To adapt to progressive salt enrichment, farmers will have to use rice varieties with shorter cropping duration and higher salt tolerance to preserve yield and income. The problem will likely become more severe when the amount and the duration of freshwater supply during the rice-growing period will further decrease due to sea level rise (Smajgl et al., 2015). Interviews with riceshrimp farmers in areas more prone to salinity (e.g., B n Tre) already revealed that some rice-shrimp farmers increasingly decided not to harvest the rice in some years but to leave it on the platform as better feeding ground for subsequent shrimp cultivation (personal communication with farmers). Therefore, it is reasonable to assume that these farmers will change from alternating rice-shrimp to permanent shrimp systems in the near future if they have the financial capacities. However, besides the loss of agricultural diversity and income for the farmers this will foster the increase in soil salinity and sodicity, thereby increasing the pressure of neighbor farmers also to give up rice cultivation. Furthermore, higher application rates of antibiotics (mostly co-applied with the shrimp feed) and higher accumulation in the soil can be expected increasing the risk of cross-contaminations of other adjacent systems. This is supported by results from our separate study using the same sample set in which we focused on the pollution patterns of pesticides and antibiotics in the respective three land use systems (Braun et al., 2019). Here we could show that antibiotic residues showed elevated concentrations in the permanent shrimp system compared to the alternating rice-shrimp and the permanent rice systems and that the alternating rice-shrimp present a low risk option for environmental pollution with pesticides and antibiotics and in terms of food safety.

The observed slight acidity ( $\sim \mathrm{pH} 5)$ of the permanent rice systems was in the range typical for well-developed paddy rice topsoils (Kögel-Knabner et al., 2010). Large differences in the pHvalues were observed between the alternating rice-shrimp systems in the two provinces. In Sóc Trăng, the pH-value of the riceplatform was similar to the permanent rice system (5.3 vs. 5.9). The $\mathrm{pH}$ of the sludge in the rice-shrimp system was more acidic than the permanent shrimp sludge (6.8 vs. 7.9), most likely due to the frequent change between fresh and brackish water, whereas the $\mathrm{pH}$ for the ditch-soil underneath the sludge was the same as found for shrimp-soil. By contrast, all compartments of the riceshrimp systems in B $\mathrm{n}$ Tre were characterized by significantly lower pH-values (ranging from $\mathrm{pH} 3.9$ to 4.1 ) as compared to the other systems of both provinces. This can be explained by the presence and exposure of pedogenic (potential) acid sulfate soil layers in all rice-shrimp systems in $\mathrm{B} \mathrm{n}$ Tre and corresponds to the observed higher $S_{t}$ concentrations (10.4 to $13.0 \mathrm{mg} \mathrm{S}_{\mathrm{t}} \mathrm{kg}^{-1}$ ) compared with the other systems (never higher than $3.5 \mathrm{mg} \mathrm{S}_{\mathrm{t}} \mathrm{kg}^{-1}$ ). It is likely that also the elevated $S_{t}$ concentrations of the soil from the permanent shrimp systems in $\mathrm{B} n$ Tre are a caused by the presence of sulfuric horizons, which however seams less developed than in the rice-shrimp systems as also indicated by the higher
$\mathrm{pH}$ (Table 1). This suggest that high $S_{t}$ values for the permanent shrimp and especially the rice-shrimp systems in B $\mathrm{n}$ Tre are not solely caused by the shrimp-management, but also due to closer exposure to sulfuric soil horizons. The impact of native sulfuric soil horizons was also reflected in the higher relative proportions of FeS and $\mathrm{FeS}_{2}$ (Table $\mathrm{S} 3$, Supporting Information) in the rice-shrimp systems from B n Tre compared to Sóc Trăng. The also observed higher proportions of $\mathrm{FeSO}_{4}$ or $\mathrm{SO}_{4}$ sorbed to $\mathrm{Fe}$ (hydr)oxides agreed to the dominance of $\mathrm{NaOH}$ extractable $\mathrm{S}$.

However, $S_{t}$ data from the other sites not affected by (potential) acid sulfate soil layers clearly confirmed that shrimp-cultivation leads to a significant enrichment of $\mathrm{S}_{\mathrm{t}}$ in soils and sludges via sea water intake, especially in stable fractions (Fig. 3; Table S2, Supporting Information). This finding can be related to the high $\mathrm{Fe}_{\mathrm{t}}$ concentration in the soils and the longer flooding that favored the formation of stable bonding forms such as Fe-sulfides as indicated by S XANES (Fig. 4; Table S3, Supporting Information) while reducing the risk that toxic dissolved $\mathrm{H}_{2} \mathrm{~S}$ concentrations were formed. However, elevated total $S_{t}$ and sulfide accrual may exert negative impacts after oxidation on both the shrimps itself, as well as on adjacent rice crops, thus impairing the reversibility of land use change.

In summary, especially $\mathrm{S}$ concentrations and bonding forms reflect both regional and land use influences on overall biogeochemical nutrient cycling. This is likely because, in contrast to other elements, $\mathrm{S}$ is much more prone to all, inputs from the seawater and parent material, as well as redox-mediated changes in soil milieu.

Notably, the feeding of shrimps on the remaining rice platform did not impair other soil properties in the alternating rice-shrimp systems. Indeed, the overall soil nutrient status of this system was similar or even improved relative to permanent rice cropping (Table 1 ). In addition, discussions with the farmers indicated a reduced fertilizer requirement for cultivating rice on the platform of the rice-shrimp system (personal communication). Likely, there was a redistribution of nutrients via shrimp and (micro-)organisms in the system as well as of feed residues that increase the concentration and availability of nutrients in platform soils for subsequent rice cultivation (Chowdhury et al., 2011). The described processes may compensate for accelerated nutrient leaching due to prolonged saline water logging (Douglas, 1994; Flaherty et al., 1999).

In contrast to alternating rice-shrimp production, a pond must be constructed for the permanent shrimp system (Fig. 1). The soil properties in these systems thus largely reflect those of former subsoil, subsequently altered by recent management and material translocations over the time (Table 1). This was in agreement to the elevated $\mathrm{pH}$ values in the permanent shrimp soils due to both higher $\mathrm{pH}$ buffering capacity of exposed former subsoil parent material as well as prolonged submergence application of lime (e.g., $\mathrm{CaCO}_{3}$ and $\mathrm{CaMg}\left(\mathrm{CO}_{3}\right)_{2}$ ) for densification during pond preparation and adjustment of water alkalinity (e.g., Boyd, 1990), as this was the case for Sóc Trăng, whereas the acidic pH values in B $\mathrm{n}$ Tre could not be avoided as indicated above by the probably exposing of sulfuric subsoil materials.

Along with the elevated $\mathrm{pH}$ and $\mathrm{EC}_{2.5}$ values, significant higher total and available $\mathrm{Ca}$ and $\mathrm{Mg}$ concentrations were maintained in all shrimp cultivating system than in the respective permanent rice systems. Calcium and Mg are, among other minerals, major parts of the shrimp shell and are thus important for shell formation and thus shrimp development (NRC, 2015). In addition, to lime application and saltwater input via shrimp residues (shells, dead animals), shrimp cultivation thus promoted the accumulation of $\mathrm{Ca}$ and $\mathrm{Mg}$ in the soils. This effect was more pronounced in the permanent shrimp systems due to higher number of shrimp cycles per year 
than in the alternating rice-shrimp system. However, we did not detect these effects in the mineral soil but only in the sludge layer above, which was thus the major sink - at least for Ca - even if in $\mathrm{B} \mathrm{n}$ Tre the presence of acid sulfate layers and associated lower $\mathrm{pH}$ values upon drainage counteracted with this Ca accumulation (Table 1 ). As revealed by S XANES, this shrimp induced Ca accumulation led to formation of $\mathrm{CaSO}_{4}$ in the directly shrimp influenced sampled compartments (sludge, platform), whereas in permanent rice and the rice-shrimp systems in $\mathrm{B} \mathrm{n}$ Tre $\mathrm{FeSO}_{4}$ was formed (Table S3).

The general low use-efficiency of $\mathrm{P}$ in of applied shrimp feed (e.g., Avnimelech and Ritvo, 2003; Dien et al., 2018; FungeSmith and Briggs, 1998) and the elevated P sorption capacity of the pond bottom (Boyd and Munsiri, 2010) led to the observed shrimp induced accumulation of $\mathrm{P}_{\mathrm{t}}$. Similar accumulation patterns of $\mathrm{P}_{\mathrm{t}}$ at the bottom of shrimp and fishponds has been reported in other studies (e.g., Avnimelech and Ritvo, 2003; Boyd et al., 1994). Iron and Al-P were the major P bonding form in all samples due to typical the high concentrations of Fe and $\mathrm{Al}$ in these tropical soils. However, as also revealed by P XANES, the enrichment of $\mathrm{Ca}$ and $\mathrm{Mg}$ promoted the accumulation of $\mathrm{P}$ within more stable bonding forms, i.e., Mg-P, and Ca-P especially in the permanent shrimp systems (Fig. 4 and Table S3, Supporting Information), which was also supported by increased proportions of stable P factions in these samples (Fig. 3 and Table S1, Supporting Information). These forms are not readily available to plants, similar to the large proportions and concentrations of occluded Fe- and Al- associated $\mathrm{P}_{\mathrm{i}}$ forms commonly found in the HCLand $\mathrm{NaOH}-\mathrm{P}$ pools and also include in the large proportions of Fe-P revealed by P XANES (Figs. 3, 4 and Table S1, S3, Supporting Information; (Negassa and Leinweber, 2009). However, our data showed that despite the shrimp induced accumulation of $\mathrm{P}_{t}$ total concentrations of labile P did not increase accordantly relative to the permanent rice systems. This might be explained by 1) the above-mentioned favored formation of more stable $P$ forms, 2) differences in the form and thus availability of P added to the systems (mineral P fertilizer $v$ s. organic $P$ in feed), and 3) exposure of stable former subsoil $\mathrm{P}$ during pond construction. On the other hand, the impact of shrimp cultivation on the concentrations of total and labile $P$ in the soils of the rice-shrimp platform was site-specific. The depletion of $\mathrm{P}_{\mathrm{t}}$ and labile $\mathrm{P}$ in the platform soils from Sóc Trăng can be explained by the missing or reduced mineral $\mathrm{P}$ fertilization and continuous plant $\mathrm{P}$ uptake, which could not be compensated by additional input of $P$ in organic form via shrimp and feed residues. By contrast, no difference or even elevated concentrations of total and labile $P$ were observed for the platform in $\mathrm{B} n$ Tre, possibly because the overall plant $\mathrm{P}$ uptake is reduced due to more severe salinity problems and the presence of acid sulfate soil layers at these sites.

The SOM and thus SOP concentrations are usually decreasing with increasing soil depth (e.g., Koch et al., 2018). The removal of SOP enriched paddy topsoil (SOP concentrations approx. 15 to $20 \% \mathrm{P}_{\mathrm{t}}$, Table S1, Supporting Information) during ditch and pond construction thus exposed fresh subsoil to the surface with inherent lower SOP concentrations. In parts, this dilution of SOP contents was compensated by the accumulation of organic P during shrimp cultivation as indicated by comparable trends revealed by $P$ fractionation and P XANES (Tab S1, S3, Supporting Information) likely from shrimp and feed residues mainly in the form of Pmonoesters (Table 1). It has to be noted that, observed divergences between both methods can be attributed to the fact that $P$ fractionation is extraction based and thus accesses only the extractable P whereas P XANES access the bulk total $\mathrm{P}$ in the sample without possible alterations due to sample treatments (e.g., hydrolyses of organic P compounds). On the other hand, P XANES access only total Fe-P and cannot differentiate whether organic or inorganic
P is associated to Fe. Thus, it is likely that both methods underestimate contributions of organic P.

In a similar manner, shrimp cultivation and the exposure of subsoil material during ditch and pond excavation likely also allocated other elements to the new soil surface, such as pristine higher $\mathrm{Zn}_{\mathrm{t}}$ contents (Table 1), which gets further enriched in the sediment by shrimp feed residues, which often is exceeding animal demand (Avnimelech and Ritvo, 2003; NRC, 2015).

Generally, SOC accumulates under the anaerobic conditions of paddy rice cultivation (Sahrawat, 2004; Wu et al., 2012; Kalbitz et al., 2013). At the sites under study the SOC concentrations of the permanent rice systems were lower $\left(12\right.$ to $\left.19 \mathrm{~g} \mathrm{~kg}^{-1}\right)$ than reported for other paddy soils of the world (20 to $29 \mathrm{~g} \mathrm{SOC} \mathrm{kg}^{-1}$; Kögel-Knabner et al., 2010), which might be attributed to the silty texture of the study sites compared with clayey texture elsewhere. The elevated SOC concentrations of the rice-shrimp platforms were unexpected, because the lower number of annual rice crop cycles ( 1 vs. 2 to 3 ) should result in lower inputs of plant residues relative to permanent rice. However, also rice straw is left on the platform as feeding ground for the shrimps. Besides, these platforms experience a more prolonged and deeper water logging, as well as additional $\mathrm{C}$ inputs from shrimp residues.

By contrast, the observed drastic decrease in the contents of SOC and $\mathrm{N}_{\mathrm{t}}$ in the soils from permanent shrimp agriculture or from the ditches of the rice-shrimp systems links to the exposure of fresh subsoil material with low inherent SOM contents during ditch and pond excavation. These reduced SOC contents now offer new potentials for $C$ sequestration. At some sites, mainly at Sóc Tra ng there were even elevated or at least similar $\mathrm{N}_{\mathrm{t}}$ concentrations at the rice-shrimp -platform and topsoils under permanent rice, likely reflecting a starting enrichment of $\mathrm{N}$ via shrimp residues (Burford and Longmore, 2001).

\subsection{Chemical properties and management of the sludge in shrimp influenced ponds and ditches}

The formation of sludge (accumulated sediment) on top of the pond bottom is common in many types of aquaculture (Boyd, 2012). In contrast to ponds with, e.g., concrete reinforced banks, the sludge material of ponds with natural banks, as investigated here, mainly originated $(\sim 97 \%)$ from eroded pond material (Funge-Smith and Briggs, 1998). The additional continuous input and accumulation of shrimp and feed residues as well as of saltwater constituents during shrimp cultivation led to the observed difference in the chemical composition between the overlaying sludge and the soil beneath (see Tables 1, 2, and Figs. 3, 4). Thereby the above-discussed effects by introducing shrimps into the systems were usually even more pronounced in the sludges than in the ditch or pond soils beneath. The elevated concentrations of SOC in the sludges from the rice-shrimp systems compared to the permanent shrimp systems can be explained by additional input of SOC enriched material eroded from the rice platform and a less frequent pond bottom treatment compared to the permanent shrimp system. Especially in the permanent shrimp systems, a regular pond bottom treatment (pond bottom liming, dry-out, or sludge removal) is important to remove accumulated organic matter and increase its decomposition rates (e.g., Li et al., 2014). This minimize the risks of impaired shrimp growth due to excessive organic matter and nutrient element loadings, production of hydrogen sulphide, and anaerobic metabolites that can be toxic to shrimps, as well as due to the accumulation of pathogens and vectors of pathogens (Boyd and Bowman, 2017).

Also small-scale farmers are aware of this problem and treat the sludge at the pond bottom in between shrimp cycles by drying it out, tilling and liming, which is environmentally more friendly with lower costs to oxidize the wastes and to eliminate predators 
and pathogens. A more or less regular removal of the sludge is also a common in the region, taking place every two to three years or after crop fail, but more this is more expensive and environmentally less friendly. The sludges are then flushed or pumped out with the drained water or they are excavated. This procedure removes SOM, salts and several plant available and organically bound nutrients, like $\mathrm{NaHCO}_{3}-\mathrm{P}$ and SOP in the form of monoester-P from the system (Tables 1, 2, S1, Supporting Information).

The frequent removal of the nutrient enriched sludge (see Table 1) from the pond bottom is essential for pond health but also can reduce pond bottom soil fertility (Boyd and Bowman, 2017; Yuvanatemiya and Boyd, 2006). Hopkins et al. (1994) reported that sludge removal significantly reduced inorganic nutrient concentrations (especially ammonia-nitrogen and orthophosphate) in the pond water and, as a result, significantly reduced the concentration of phytoplankton. Our data showed, however, that this treatment did not impair the overall nutrient status of the pond soils, which still exhibited elevated nutrient contents, possibly because sludge removal was incomplete or leaching of nutrients from the sludge into the soils underneath. Nevertheless, removing the sludge and off-farm disposal of the material into the rivers can possess serious environmental and economic problems as this facilitates (1) spread of diseases between shrimp farms, (2) cross-contamination (e.g., antibiotics from shrimp feed residues) between land use systems, and (3) eutrophication and salinization of waterbodies. The observed elevated high nutrient contents in the sludge make it prone to off-farm reuse as soil fertilizer or conditioner also in other cropping systems after the leaching of excessive salts on welldrained soils. Such a re-use of material would likely be safer in the alternating rice-shrimp than in the permanent shrimp systems, due to lower salt loads and lower risks for cross-contamination with antibiotics in the former (Braun et al., 2019).

\section{Conclusions}

We show that shrimp farming has a specific fingerprint in terms of landscape morphology and nutrient status in the soil and sludges, which gets more pronounced with an increasing intensity of shrimp-cultivation (alternating < permanent shrimp cultivation). Shrimp cultivation leads to increased soil salinity and sodicity, while concentrations of essential plant nutrients are maintained or even increased relative to former permanent rice systems. The continued deposition of shrimp and feed debris promoted the accrual of SOC and stable Ca- and Mg-associated P forms as well as of P-monoesters, whereas the $\mathrm{S}$ forms were depleted in thiophene $\mathrm{S}$ groups but enriched in sulfides relative to permanent rice fields.

However, soil fertility is also controlled by landscape morphology. The construction of shrimp pond has a massive impact on further land use options. Even if the salts can be washed out, the nutrient-rich pond soils are no longer suitable for other crops because the shrimp ponds would need to be first filled up again to re-join the irrigation and drainage schemes. The refilling of the ponds would need large amounts of soil and according to our interviews this is currently not discussed. Refilling would have unknown effects on the restoration of physical and chemical soil properties as well as hydrology.

The alternating rice-shrimp farming system appears to be a fully reversible and a return to permanent rice is according to our discussions with farmers a viable option, as only the ditches have to be refilled. Furthermore, it allows farmers to respond to temporally changes in the salinity (e.g., extreme drought seasons) by increasing the number of shrimp crop cycles. Therefore, our results support our hypothesis that the alternating rice-shrimp farming can be seen as no-regret strategy for farmers as it preserves their flexibility to respond to future climate changes in areas with recurrent temporally salinity intrusion.

By contrast, switching to the shrimp system can create path dependencies and lock-in effects for farmers and increases economical risks (Amoako Johnson et al., 2016; Tu, 2019). However, in coastal areas affected throughout the year by salinity intrusion and with not enough freshwater available to grow rice even in the rainy season, permanent shrimp systems provide larger revenues. In any case, switching former rice-based systems to alternating or permanent shrimp production changes soil properties. However, alternating rice-shrimps systems have the clear additional advantage to maintain flexibility in terms of future land uses, whereas permanent intensive shrimp land use would create path dependencies, which has to be considered in future land use planning for the coastal area of the Mekong Delta.

\section{Declaration of Competing Interest}

The authors declare that they have no known competing financial interests or personal relationships that could have appeared to influence the work reported in this paper.

\section{Acknowledgements}

We thank V. T. Guong, D. M. Vien, T. H. Khanh, D. B. Tan, and F. Renaud for help during site selection and sampling in the field, $\mathrm{N}$. Siebers, E. Heilman, A. Kiener, K. Unger, and P. Narf for help during lab analyses as well as Y. Hu from the SXRMB (CLS) beamline for technical support during XANES measurements. The XANES experiments were performed at the Canadian Light Source, a national research facility of the University of Saskatchewan, which is supported by the Canada Foundation for Innovation (CFI), the Natural Sciences and Engineering Research Council (NSERC), the National Research Council (NRC), the Canadian Institutes of Health Research (CIHR), the Government of Saskatchewan, and the University of Saskatchewan. The research was funded by the German Ministry of Education and Science (BMBF) in the frame of the project DeltAdapt (FKZ 031A287A).

\section{Appendix A. Supplementary data}

Supplementary data to this article can be found online at https://doi.org/10.1016/j.scitotenv.2019.134758.

\section{References}

Amoako Johnson, F., Hutton, C.W., Hornby, D., Lázár, A.N., Mukhopadhyay, A., 2016. Is shrimp farming a successful adaptation to salinity intrusion? A geospatial associative analysis of poverty in the populous Ganges-Brahmaputra-Meghna Delta of Bangladesh. Sustain. Sci. 11, 423-439. https://doi.org/10.1007/s11625016-0356-6.

Atapattu, S., Molden, D., 2006. Achieving food and environmental security: better river basin management for healthy coastal zones. In: Hoanh, C.T., Tuong, T.P., Gowing, J.W., Hardy, B. (Eds.), Environment and livelihoods in tropical coastal zones: managing agriculture-fishery-aquaculture conflicts. CABI, Wallingford, pp. 293-301. https://doi.org/10.1079/9781845931070.0293.

Avnimelech, Y., Ritvo, G., 2003. Shrimp and fish pond soils: processes and management. Aquaculture 220, 549-567. https://doi.org/10.1016/S0044-8486 (02)00641-5.

Boyd, C.E., 2012. Bottom soils, sediment, and pond aquaculture. Springer Science \& Business Media.

Boyd, C.E., 1990. Water quality in ponds for aquaculture. Alabama Agricultural Experiment Station, Auburn university. Alabama P462, 482.

Boyd, C.E., Bowman, J.R., 2017. Pond bottom soils, in: Dynamics of Pond Aquaculture. https://doi.org/10.1201/9780203759028.

Boyd, C.E., Munsiri, P., 2010. Phosphorus adsorption capacity and availability of added phosphorus in soils from aquaculture areas in Thailand. J. World Aquac. Soc. 27, 160-167. https://doi.org/10.1111/j.1749-7345.1996.tb00265.x. 
Boyd, C.E., Tanner, M.E., Madkour, M., Masuda, K., 1994. Chemical characteristics of bottom soils from freshwater and brackishwater aquaculture ponds. J. World Aquac. Soc. 25, 517-534. https://doi.org/10.1111/j.1749-7345.1994.tb00821.x.

Braun, G., Braun, M., Kruse, J., Amelung, W., Renaud, F.G., Khoi, C.M., Duong, M.V., Sebesvari, Z., 2019. Pesticides and antibiotics in permanent rice, alternating rice-shrimp and permanent shrimp systems of the coastal Mekong Delta. Vietnam. Environ. Int. 442-451. https://doi.org/10.1016/j.envint.2019.03.038.

Burford, M.A., Longmore, A.R., 2001. High ammonium production from sediments in hypereutrophic shrimp ponds. Mar. Ecol. Prog. Ser. 224, 187-195. https://doi. org/10.3354/meps224187.

Cade-Menun, B.J., Carter, M.R., James, D.C., Liu, C.W., 2010. Phosphorus forms and chemistry in the soil profile under long-term conservation tillage: a phosphorus-31 nuclear magnetic resonance study. J. Environ. Qual. 39, 1647. https://doi.org/10.2134/jeq2009.0491.

Cade-Menun, B.J., Preston, C.M., 1996. A comparison of soil extraction procedures for 31P NMR spectroscopy. Soil Sci. 161, 770-785. https://doi.org/10.1097/ 00010694-199611000-00006.

Chowdhury, M.A., Khairun, Y., Salequzzaman, M., Rahman, M.M., 2011. Effect of combined shrimp and rice farming on water and soil quality in Bangladesh. Aquac. Int. 19, 1193-1206. https://doi.org/10.1007/s10499-011-9433-0.

Das, M., Verma, O.P., Swain, P., Sinhababu, D.P., Sethi, R., 2017. Impact of brackishwater shrimp farming at the interface of rice growing areas and the prospects for improvement in coastal India. J. Coast. Conserv. 21, 981-992. https://doi.org/10.1007/s11852-017-0567-8.

Alliance, Delta, 2011. Mekong delta water resources assesment studies., Viet namNeetherlands Mekong. Delta Masterplan project.

Dien, L.D., Hiep, L.H., Hao, N. Van, Sammut, J., Burford, M.A., 2018. Comparing nutrient budgets in integrated rice-shrimp ponds and shrimp grow-out ponds. Aquaculture 484, 250-258. https://doi.org/10.1016/j.aquaculture.2017.11.037.

Don, A., Schumacher, J., Freibauer, A., 2011. Impact of tropical land-use change on soil organic carbon stocks - a meta-analysis. Glob. Chang. Biol. https://doi.org/ 10.1111/j.1365-2486.2010.02336.x.

Doolette, A.L., Smernik, R.J., Dougherty, W.J., 2009. Spiking Improved Solution Phosphorus-31 Nuclear Magnetic Resonance Identification of Soil Phosphorus Compounds. Soil Sci. Soc. Am. J. 73, 919. https://doi.org/10.2136/ sssaj2008.0192.

Douglas, I., 1994. Land Degradation in the Humid Tropics, in: Roberts, N. (Ed.), The Changing Global Environment. pp. 332-350.

Dung, L., 2012. Impact of growing rice on shrimp culture through economic indicators in rice - shrimp system in coastal region in the Mekong Delta. Can Tho Univ. J. Sci., 69-77

Egashira, K., Takenaka, J., Shuto, S., Moslehuddin, A.Z.M., Takenaka, J., Shuto, S., Moslehuddin, A.Z.M., 2003. Phosphorus status of some paddy soils in Bangladesh. Soil Sci. Plant Nutr. 49, 751-755. https://doi.org/10.1080/ 00380768.2003.10410335.

Erban, L.E., Gorelick, S.M., Zebker, H.A., 2014. Groundwater extraction, land subsidence, and sea-level rise in the Mekong Delta. Vietnam. Environ. Res. Lett. 9. https://doi.org/10.1088/1748-9326/9/8/084010.

Fageria, N.K., Gheyi, H.R., Moreira, A., 2011. Nutrient bioavailability in salt affected soils. J. Plant Nutr. 34, 945-962. https://doi.org/10.1080/01904167. 2011.555578.

FAO, 2015. Guidelines for soil description. https://doi.org/10.1016/S0341-8162(99) 00067-3

Flaherty, M., Vandergeest, P., Miller, P., 1999. Rice paddy or shrimp pond: Tough decisions in Rural Thailand. World Dev. 27, 2045-2060. https://doi.org/ 10.1016/S0305-750X(99)00100-X.

Funge-Smith, S.J., Briggs, M.R.P., 1998. Nutrient budgets in intensive shrimp ponds: Implications for sustainability. Aquaculture., 117-133 https://doi.org/10.1016/ S0044-8486(98)00181-1.

Gillman, G.P., Sumpter, E.A., 1986. Modification to the compulsive exchange method for measuring exchange characteristics of soils. Aust. J. Soil Res. 24, 61-66. https://doi.org/10.1071/SR9860061.

GSO-Database, 2017. General Statistic Office in Vietnam, Database [WWW Document]. URL https://www.gso.gov.vn/default_en.aspx?tabid=778 (accessed 9.20.07)

GSO-Database, 2016. General Statistic Office in Vietnam, Database [WWW Document]. URL https://www.gso.gov.vn/default_en.aspx?tabid=774 (accessed 9.20.06).

GSO, 2018. Statistical Yearbook of Vietnam 2018, General Statistics Office, Vietnam.

GSO, 2016. Statistical Yearbook of Vietnam 2016, General Statistics Office, Vietnam.

Guo, L.B., Gifford, R.M., 2002. Soil carbon stocks and land use change: A meta analysis. Glob. Chang. Biol. 8, 345-360. https://doi.org/10.1046/j.13541013.2002.00486.x.

Hai, T., Pham, M., Duc, N., Minh, T., Nguyen, P., 2015. Innovation of marine shrimp seed production and farming in Vietneam.

Hopkins, J.S., Sandifer, P.A., Browdy, C.L., 1994. Sludge management in intensive pond culture of shrimp: Effect of management regime on water quality, sludge characteristics, nitrogen extinction, and shrimp production. Aquac. Eng. 13, 1130. https://doi.org/10.1016/0144-8609(94)90022-1.

Hu, Y.F., Coulthard, I., Chevrier, D., Wright, G., Igarashi, R., Sitnikov, A., Yates, B.W., Hallin, E.L., Sham, T.K., Reininger, R., 2010. Preliminary commissioning and performance of the soft x-ray micro-characterization beamline at the Canadian light source. AIP Conference Proceedings., 343-346 https://doi.org/10.1063/ 1.3463208 .

Joffre, O.M., Poortvliet, P.M., Klerkx, L., 2018. Are shrimp farmers actual gamblers? An analysis of risk perception and risk management behaviors among shrimp farmers in the Mekong Delta. Aquaculture 495, 528-537. https://doi.org/ 10.1016/j.aquaculture.2018.06.012.

Koch, M., Kruse, J., Eichler-Löbermann, B., Zimmer, D., Willbold, S., Leinweber, P. Siebers, N., 2018. Phosphorus stocks and speciation in soil profiles of a longterm fertilizer experiment: Evidence from sequential fractionation, P K-edge XANES, and 31P NMR spectroscopy. Geoderma 316, 115-126. https://doi.org/ 10.1016/j.geoderma.2017.12.003.

Kögel-Knabner, I., Amelung, W., Cao, Z., Fiedler, S., Frenzel, P., Jahn, R., Kalbitz, K. Kölbl, A., Schloter, M., 2010. Biogeochemistry of paddy soils. Geoderma. https:/ doi.org/10.1016/j.geoderma.2010.03.009.

Kölbl, A., Schad, P., Jahn, R., Amelung, W., Bannert, A., Cao, Z.H., Fiedler, S., Kalbitz, K., Lehndorff, E., Müller-Niggemann, C., Schloter, M., Schwark, L., Vogelsang, V. Wissing, L., Kögel-Knabner, I., 2014. Accelerated soil formation due to paddy management on marshlands (Zhejiang Province, China). Geoderma 228-229, 67-89. https://doi.org/10.1016/j.geoderma.2013.09.005.

Li, L., Queiroz, J.F., Boyd, C.E., 2014. Pond Bottom Dryout, Liming. Glob. Aquac Advocate 17, 34-35.

Lilienfein, J., Wilcke, W., Ayarza, M.A., Vilela, L., Do Carmo Lima, S., Zech, W., 2000 Chemical fractionation of phosphorus, sulphur, and molybdenum in Brazilian savannah Oxisols under different land use. Geoderma 96, 31-46. https://doi. org/10.1016/S0016-7061(00)00002-1

Minderhoud, P.S.J., Erkens, G., Pham, V.H., Bui, V.T., Erban, L., Kooi, H., Stouthamer E., 2017. Impacts of 25 years of groundwater extraction on subsidence in the Mekong delta. Vietnam. Environ. Res. Lett. 12. https://doi.org/10.1088/1748 9326/aa7146.

Murphy, J., Riley, J.P., 1962. A modified single solution method for the determination of phosphate in natural waters. Anal. Chim. Acta 27, 31-36. https://doi.org/10.1016/S0003-2670(00)88444-5.

Negassa, W., Leinweber, P., 2009. How does the hedley sequential phosphorus fractionation reflect impacts of land use and management on soil phosphorus: a review. J. Plant Nutr. Soil Sci. https://doi.org/10.1002/jpln.200800223.

Nguyen, M.T., Renaud, F.G., Sebesvari, Z., 2019. Drivers of change and adaptation pathways of agricultural systems facing increased salinity intrusion in coastal areas of the Mekong and Red River deltas in Vietnam. Environ. Sci. Policy 92, 331-348. https://doi.org/10.1016/j.envsci.2018.10.016.

Nhuong, T.V., Luu, L.T., Tu, T.Q., Tam, P.M., Nguyet, T.T.A., 2002. A comparative analysis of Bangladesh, India, Thailand, and Vietnam With particular reference to institutional and socio-economic aspects.

NRC, 2015. Nutrient Requirements of Fish and Shrimp, Nutrient Requirements of Fish and Shrimp. https://doi.org/10.17226/13039.

Ottinger, M., Clauss, K., Kuenzer, C., 2016. Aquaculture: Relevance, distribution, impacts and spatial assessments - A review. Ocean Coast. Manag. https://doi. org/10.1016/j.ocecoaman.2015.10.015

Pan, G., Li, L., Wu, L., Zhang, X., 2004. Storage and sequestration potential of topsoil organic carbon in China's paddy soils. Glob. Chang. Biol. 10, 79-92. https://doi. org/10.1111/j.1365-2486.2003.00717.x.

Pham, T., Tran, H., Vo, S., Trinh, T., 2015. Comprehensive review of rice-shrimp systems in Vietnam. Hi n trạng phát tri n tôm-lúa vùng $Đ$ ng b ng sông Cửu Long, In Vietnamese.

Phuong Lan, N.T., 2013. Social and ecological challenges of market-oriented shrimp farming in Vietnam. Springerplus 2, 1-10. https://doi.org/10.1186/2193-18012-675.

Reddy, P.R., Kishori, B., 2019. Integrated Rice and Aquaculture Farming, in: DiartePlata, G., Escamilla-Montes, R. (Eds.), Aquaculture - Plants and Invertebrates. pp. 11-32. https://doi.org/10.5772/intechopen.78062.

Renaud, F.G., Le, T.T.H., Lindener, C., Guong, V.T., Sebesvari, Z., 2015. Resilience and shifts in agro-ecosystems facing increasing sea-level rise and salinity intrusion in Ben Tre Province. Mekong Delta. Clim. Change 133, 69-84. https://doi.org/ 10.1007/s10584-014-1113-4.

Sahrawat, K.L., 2004. Organic matter accumulation in submerged soils. Adv. Agron. https://doi.org/10.1016/S0065-2113(03)81004-0.

Sebesvari, Z., Renaud, F.G., Haas, S., Tessler, Z., Hagenlocher, M., Kloos, J., Szabo, S., Tejedor, A., Kuenzer, C., 2016. A review of vulnerability indicators for deltaic social-ecological systems. Sustain. Sci. https://doi.org/10.1007/s11625-0160366-4.

Smajgl, A., Toan, T.Q., Nhan, D.K., Ward, J., Trung, N.H., Tri, L.Q., Tri, V.P.D., Vu, P.T., 2015. Responding to rising sea levels in the Mekong Delta. Nat. Clim. Chang. 5 , 167-174. https://doi.org/10.1038/nclimate2469.

Smith, P., House, J.I., Bustamante, M., Sobocká, J., Harper, R., Pan, G., West, P.C., Clark J.M., Adhya, T., Rumpel, C., Paustian, K., Kuikman, P., Cotrufo, M.F., Elliott, J.A. Mcdowell, R., Griffiths, R.I., Asakawa, S., Bondeau, A., Jain, A.K., Meersmans, J., Pugh, T.A.M., 2016. Global change pressures on soils from land use and management. Glob. Chang. Biol. 22, 1008-1028. https://doi.org/10.1111/ gcb. 13068 .

Solomon, D., Lehmann, J., Martínez, C.E., 2003. Sulfur K-edge XANES Spectroscopy as a Tool for Understanding Sulfur Dynamics in Soil Organic Matter. Soil Sci. Soc. Am. J. 67, 1721. https://doi.org/10.2136/sssaj2003.1721.

Sonmez, S., Buyuktas, D., Okturen, F., Citak, S., 2008. Assessment of different soil to water ratios $(1: 1,1: 2.5,1: 5)$ in soil salinity studies. Geoderma 144, 361-369. https://doi.org/10.1016/j.geoderma.2007.12.005.

Tho, N., Vromant, N., Hung, N.T., Hens, L., 2008. Soil salinity and sodicity in a shrimp farming coastal area of the Mekong Delta. Vietnam. Environ. Geol. 54, 17391746. https://doi.org/10.1007/s00254-007-0951-z.

Tiessen, H., Moir, J., 1993. Characterization of Available P by Sequential Extraction. Soil Sampling and Methods of Analysis. https://doi.org/10.1201/ 9781420005271.ch25. 
Tu, M.N., 2019. Drivers of change, adaptation and resilience of agricultural systems facing increased salinity intrusion in deltaic coastal areas. of Vietnam. University Bonn.

Turner, B.L., Cheesman, A.W., Godage, H.Y., Riley, A.M., Potter, B.V.L., 2012. Determination of neo-and D-chiro-Inositol hexakisphosphate in soils by solution 31P NMR spectroscopy. Environ. Sci. Technol. 46, 4994-5002. https:// doi.org/10.1021/es204446z.

Vietnam+, 2016. Drought affects over 13,000 households in Tra Vinh | Vietnam+ (VietnamPlus) [WWW Document]. Vietnam+. URL https://en.vietnamplus. vn/drought-affects-over-13000-households-in-tra-vinh/89991.vnp (accessed 5.15.19).

Wu, J., Zhou, P., Li, L., Su, Y., Yuan, H., Syers, J.K., 2012. Restricted mineralization of fresh organic materials incorporated into a subtropical paddy soil. J. Sci. Food Agric. 92, 1031-1037. https://doi.org/10.1002/jsfa.4645.

Yuvanatemiya, V., Boyd, C.E., 2006. Physical and chemical changes in aquaculture pond bottom soil resulting from sediment removal. Aquac. Eng. 35, 199-205. https://doi.org/10.1016/j.aquaeng.2006.02.001. 